\title{
Lifecycle of an Intermontane Plio-Pleistocene Fluvial Valley of the Northern Apennines: From Marine-Driven Incision to Tectonic Segmentation and Infill
}

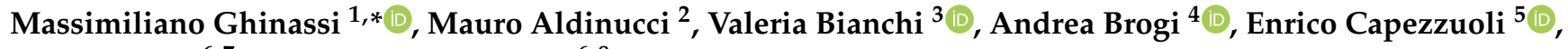 \\ Tsai-Luen $\mathrm{Yu}^{6,7}$ and Chuan-Chou Shen ${ }^{6,8}$ \\ check for \\ updates \\ 1 Department of Geosciences, University of Padova, 35131 Padova, Italy \\ 2 Eni México S. de R.L. de C.V., Mexico City 11000, Mexico; mauro.aldinucci@eni.no \\ 3 School of Earth and Environmental Sciences, The University of Queensland, Brisbane 4072, Australia; \\ valeria.bianchi2504@gmail.com \\ 4 Department of Earth and Geoenviromental Sciences, University of Bari, 70125 Bari, Italy; \\ andrea.brogi@uniba.it \\ 5 Department of Earth Sciences, University of Florence, 50121 Florence, Italy; enrico.capezzuoli@unifi.it \\ 6 High-Precision Mass Spectrometry and Environment Change Laboratory (HISPEC), Department of \\ Geosciences, National Taiwan University, Taipei 10617, Taiwan; d00224009@g.ntu.edu.tw (T.-L.Y.); \\ river@ntu.edu.tw (C.-C.S.) \\ 7 Marine Industry and Engineering Research Center, National Academy of Marine Research, \\ Kaohsiung City 806614, Taiwan \\ 8 Research Center for Future Earth, National Taiwan University, Taipei 10617, Taiwan \\ * Correspondence: massimiliano.ghinassi@unipd.it
}

Citation: Ghinassi, M.; Aldinucci, M.; Bianchi, V.; Brogi, A.; Capezzuoli, E.; Yu, T.-L.; Shen, C.-C. Lifecycle of an Intermontane Plio-Pleistocene Fluvial Valley of the Northern Apennines: From Marine-Driven Incision to Tectonic Segmentation and Infill. Geosciences 2021, 11, 141. https:// doi.org/10.3390/geosciences11030141

Academic Editors: Angelo Cipriani and Jesus Martinez-Frias

Received: 30 January 2021

Accepted: 15 March 2021

Published: 18 March 2021

Publisher's Note: MDPI stays neutral with regard to jurisdictional claims in published maps and institutional affiliations.

Copyright: (c) 2021 by the authors. Licensee MDPI, Basel, Switzerland. This article is an open access article distributed under the terms and conditions of the Creative Commons Attribution (CC BY) license (https:// creativecommons.org/licenses/by/ $4.0 /)$.
Abstract: Downcutting and infill of incised valley systems is mostly controlled by relative sea-level changes, and studies on valley-fill successions accumulated independently from relative sea-level or lake-level oscillations are limited. This study focuses on the Plio-Pleistocene evolution of a fluvial drainage system developed in Southern Tuscany (Italy) following a regional marine forced regression at the end of Piacentian. Subsequent in-valley aggradation was not influenced by any relative sea-level rise, and valley morphological and depositional history mainly resulted from interaction between sediment supply and tectonic activity, which caused segmentation of the major valley trunk into localized subsiding depocenters separated by upwarping blocks. Fluvial sedimentation occurred until late Calabrian time, when the major river abandoned that valley, where minor fluviolacustrine depocenters allowed accumulation of siliciclastic and carbonate deposits. The present study demonstrates that the infill of the valley was not controlled by the forcing that caused its incision. Accumulation of the fluvial succession is discussed here in relation with localized, tectonic-controlled base levels, which commonly prevent from establishing of a clear downdip stratigraphic correlations. Chronological reconstruction of the study depositional dynamics provides solid constrains to frame them in the tectono-sedimentary evolution of the Northern Apennines.

Keywords: fluvial sedimentology; incised valley; palaeodrainage; Southern Tuscany

\section{Introduction}

Fluvial valley systems are key geomorphic elements that act as sediment transfers from source to sink areas. Occasionally, they allow accumulation of thick sedimentary successions [1-7], which might host relevant volumes of hydrocarbons or fossil water. In the downstream valley reaches, relative sea-level changes are dominant forcings on in-valley fluvial dynamics $[1,8]$, whereas tectonic and climate are the main controls in upstream sectors $[9,10]$. Deposits accumulated in the downstream valley reaches commonly exhibit evidence of marine influence, in terms of adjustment of alluvial dynamics (e.g., tidal influence) as well as direct contribution to sedimentation (e.g., estuarine deposits). Oscillations 
of relative-sea level play a major role in triggering aggradation and degradation processes in downstream valley reaches [1]. Deposits accumulated in the upstream valley reaches have mainly fluvial origin $[1,11]$ and processes of aggradational and degradation result from the complex interaction between tectonics, climate and drainage evolution $[9,10,12]$. Downstream valley-reach deposits are much more documented in comparison to the upstream counterpart, since the latter one has a low potential of preservation or can be hardly distinguishable from the surrounding extra-valley deposits [12].

In intermontane basins valleys play a key role in transferring sediment from the orogen to the surrounding basins [13-15]. The complex tectono-morphological configuration of extensional intermontane basins, like those of Northern and Central Apennines [16,17], allows coexistence of differently-subsiding areas separated by more stable substrate ridges. Beyond relative-sea level effects and tectono-climate forcings, this tectono-morphological configuration causes rivers cutting through post-orogenic landscapes to experience a number of interconnected processes [17-20] including: (i) variation in accommodations triggered by the occurrence of localized base levels; (ii) relocation due to piracy processes and (iii) variation in sediment supply and water discharge associated with evolution of the related drainage.

Major rivers of the inner Northern Apennines (e.g., Arno, Sieve, Ombrone) modelled the present-day landscape connecting extensional intermontane basins by cutting deep and narrow gorges on pre-Neogene rocks $[18,21]$. During Pliocene to Pleistocene time, tectono-geomorphic processes assisted these rivers to interact with a marine base level and to shift between adjacent basins [21], accumulating a wide spectrum of deposits along the related palaeovalleys. Although detection of these valley-fill succession is commonly hindered by paucity of outcrops, they are a precious archive to investigate the temporal and spatial evolution of the palaeo-drainage, and the associated processes.

This study focuses on a Pliocene-Pleistocene palaeovalley developed in Central Tuscany (Northern Apennines, Italy; Figure 1). Developed across a rocky ridge that separated three major intermontane basins, it experienced complex geomorphic and depositional dynamics, since its marine-driven incision to the final piracy-driven abandonment.

This study refines previously published data [22,23] and integrates new field-based information in a larger area of interest. The paper aims at depicting the depositional history of this palaeovalley through a multidisciplinary approach, which includes field mapping, sedimentary facies analyses, radiometric datings, palaeocurrent studies, and tectonostratigraphic investigations. Beyond providing new insights to the regional geology, results from this study will be discussed in comparison with current facies models for valley-fill successions and also to highlight implication for the tectono-stratigraphic evolution of the Northern Apennines [24-26]. This work adopts the International Chronostratigraphic Chart v2020/03 nomenclature. 


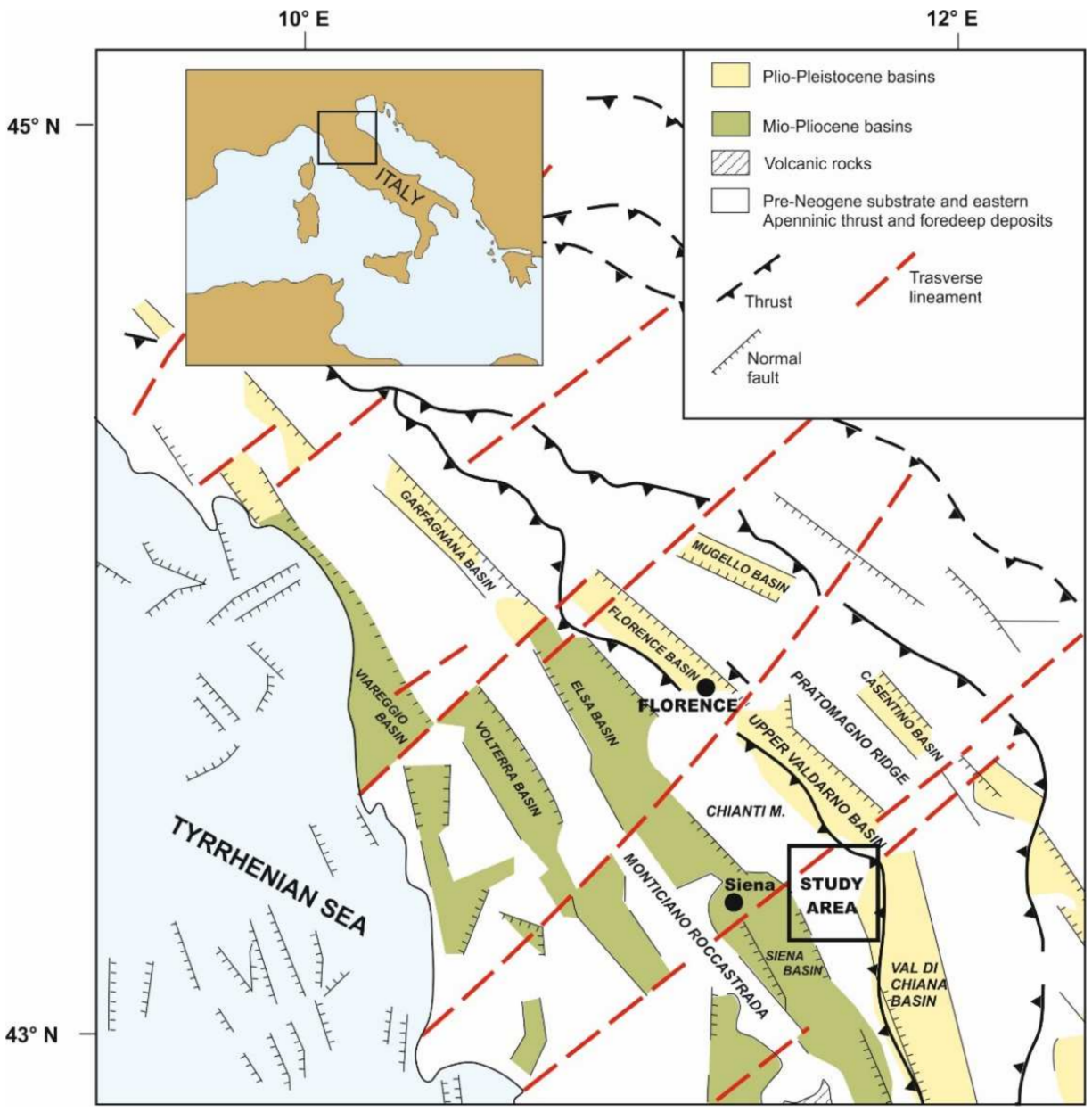

Figure 1. Tectonic map of the Northern Apennines, with indication of the main Neogene-Quaternary intermontane basins (Modified after [27]). Location of the study area is shown.

\section{Geological Setting}

After the collisional event that gave rise to the Northern Apennines (Late OligoceneEarly Miocene), a widespread extensional event produced the thinning of the previously overthickened continental crust $[24,25]$ favoring the development of a Basins-and-Ranges upper-crustal architecture, especially in the inner zone of the belt (i.e., northern Tyrrhenian Sea and southern Tuscany) [16]. Extensional tectonics and related structural depressions (i.e., basins) have been migrating from west to east, thus the inland westernmost basins are the oldest ones [26]. In this view, the progressive eastward migration produced the development of intermontane basins, which evolution was characterized by an extensive tectonic activity conditioning the sedimentation $[28,29]$.

The study area is drained by hydrographic systems pertaining to three major intermontane basins, namely the Upper Valdarno, Siena and Val di Chiana Basin (Figures 1-3). This area forms a narrow, elongated belt, that, for sake of simplicity, has been divided into three sectors based on the occurrence of three major faults (faults F1 to F3 in Figures 2 and 3, sectors are visible in Figure 3). Sector 1 and 2 are sited within the modern drainage system pertaining to the Upper Valdarno and Siena Basins, respectively, whereas sector 3 is sited in the drainage of the modern Val di Chiana Basin. Sector 1 is drained by the modern Ambra River (Figure 3), which after flowing southward for a few kilometers bends northward to join the Arno River in the Upper Valdarno Basin. Sector 2 is drained by the southward-flowing Ombrone River, which deeply cuts Pliocene marine deposits of the Siena Basin (Figure 3). The southern part of Sector 2 is characterized by the occurrence of a flat morphological surface (Pian di Bari and Bestina plain) that contrasts with the 
hilly landscape generated by the erosion of marine sediments, and caps the study deposits. Sector 3 is drained by the Foenna Creek (Figure 3), located at the bottom of a wide plain within the Sentino Basin (Figure 3). The Foenna Creek is sourced from the Rapolano area and drains eastward toward the Val di Chiana Basin (Figure 3).

The Upper Valdarno Basin is located about $35 \mathrm{~km}$ SE of Florence, between the Chianti Mountains and the Pratomagno Ridge, and it is filled with a few hundred meters of palustrine, lacustrine and alluvial deposits [30-33]. The basin fill succession consists of three major unconformity-bounded stratigraphic units [33] accumulated between Piacentian and Chibanian. The Calabrian to Chibanian depositional history of the Valdarno Basin is well-constrained by integrated magnetostratigraphic [31,33] and palaeontological data [34], which reveal the entrance of the Arno River into the basin [21,35]. The Arno River flowed from the Casentino Basin (Figure 1) southward to the Val di Chiana Basin since Pliocene time [21]. A piracy event caused the northward deflection into the Upper Valdarno Basin just before the Matuyama/Brunhes geomagnetic polarity transition $[33,36]$. In the basin fill succession, this geomorphic event is documented by: (i) a basin scale unconformity [36]; (ii) the increase of depth in channel of the axial drainage systems [33] and (iii) the occurrence of distinctive calcareous clasts from the Casentino area [35] in the axial fluvial deposits.
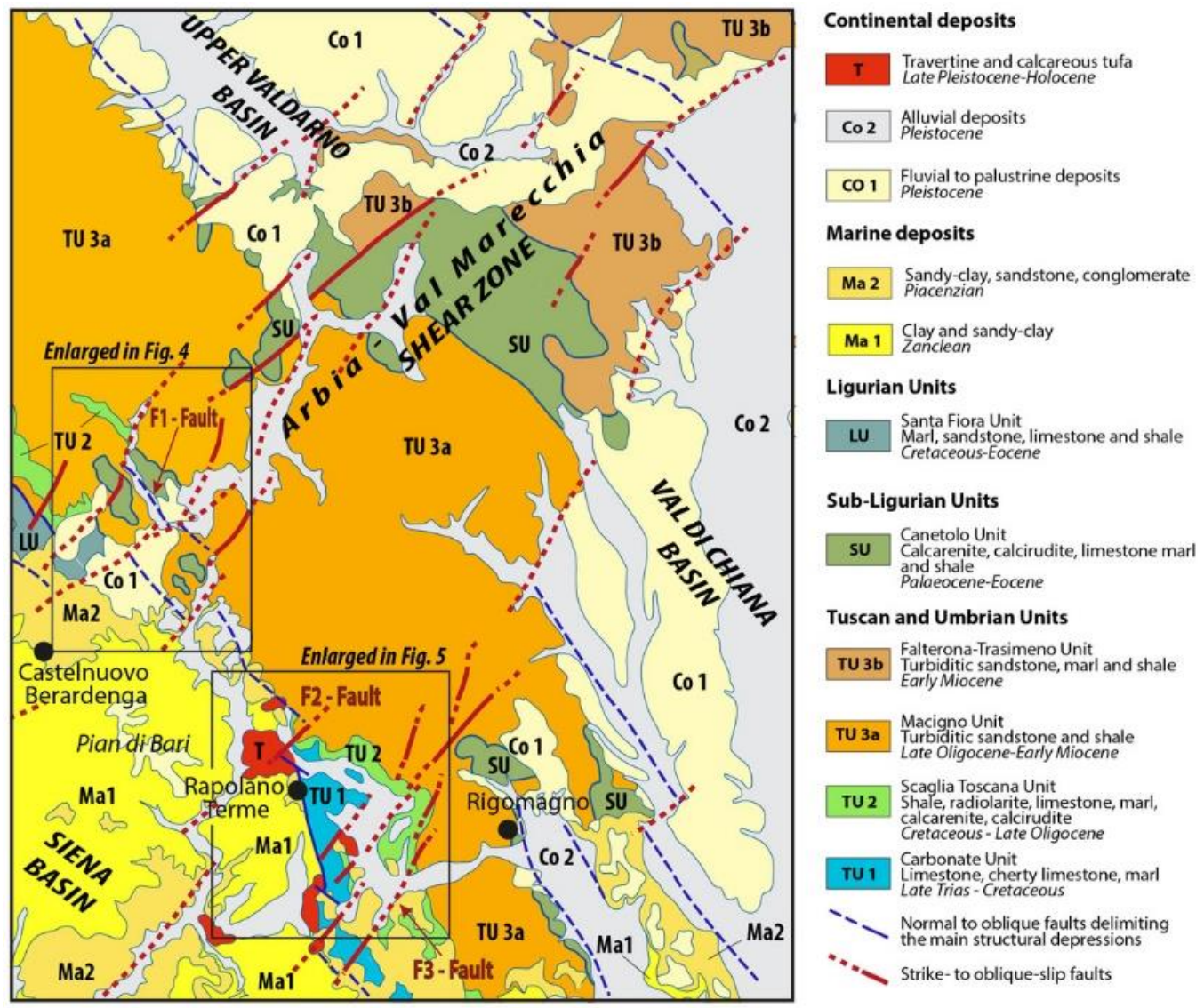

Figure 2. Geological map of the study area with indicated the enlarged areas in Figures 4 and 6. The indicated F1-F3 faults are mentioned in the text.

The Siena Basin is located about $15 \mathrm{~km} \mathrm{SE}$ of the Upper Valdarno Basin, along the western side of the Chianti Ridge, and is bounded westward by the Monticiano-Roccastrada range (Figures 1 and 2). The basin-fill succession is ca. $100 \mathrm{~m}$ thick and consists of Miocene continental deposits covered by a Pliocene marine succession [37,38]. Marine sedimentation occurred since early Zanclean and it is well-documented along the Chianti margin, in the Castelnuovo Berardenga surroundings [39-41]. In this area, coastal marine deposits present three major relative sea-level changes [41] occurred during Piacentian time. In the Siena Basin, marine sedimentation ended up in the latest Piacentian [39-41], although recent 
studies pointed out the occurrence of latest Gelasian deposits [42]. This marine succession forms the youngest substrate of the investigated succession, which appears to be the only record of deposition in the area during Gelasian to Calabrian time ([22,23] Figure 4)

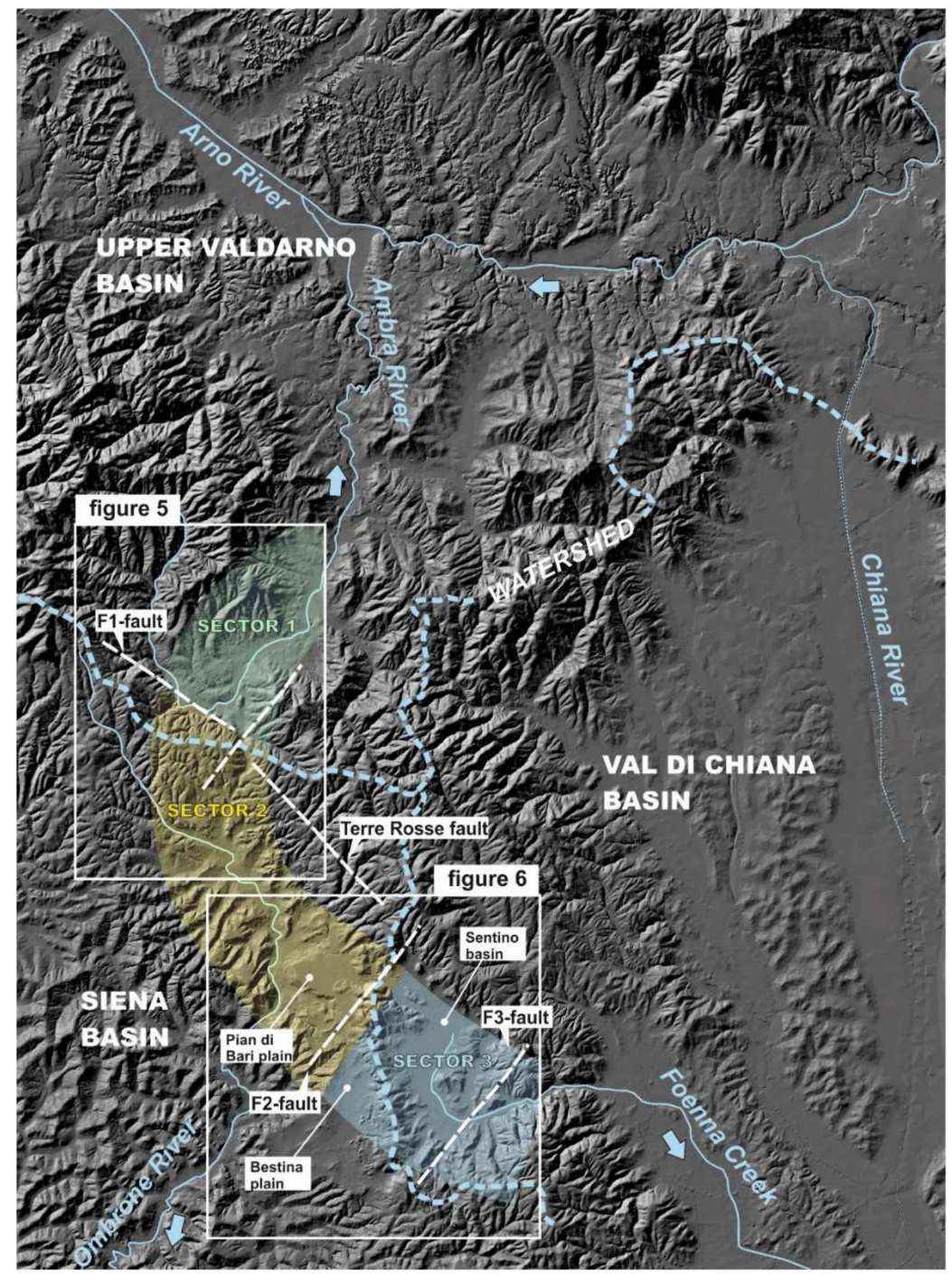

Figure 3. Geomorphological features of the study area. Watersheds separating the major drainage domains are highlighted, along with the key structural features associated with the present study (F1 to 3 faults).

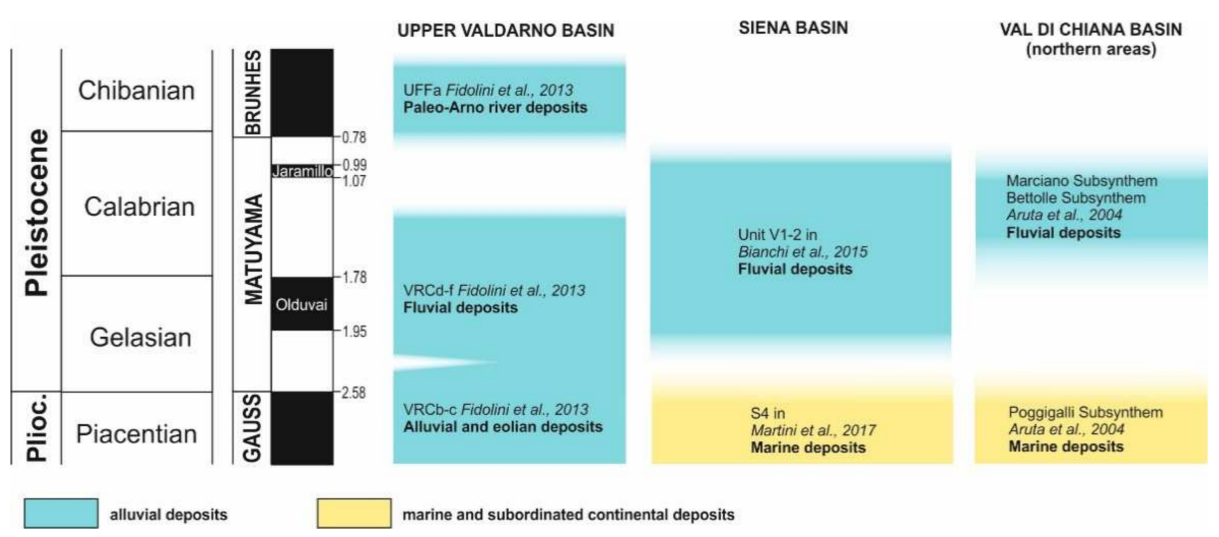

Figure 4. Age of deposits filling the Upper Valdarno, Siena and Val di Chiana Basins during PlioPleistocene time. 
The Val di Chiana Basin represents the southern extension of the Upper Valdarno Basin, and it is separated from the latter one by a 10-km-wide rocky ridge (Figures 1-3). The Val di Chiana Basin is filled up with a 1500-2000 m thick sedimentary succession [43,44], consisting of marine and alluvial deposits accumulated between Pliocene and Pleistocene time. The stratigraphy of the Northern Val di Chiana Basin fill is still poorly known, although it was recently improved by [45]. In this sector of the basin, marine sedimentation occurred in the basin until late Piacentian [44,45], and it was replaced by alluvial sedimentation during Gelasian to Calabrian time [45]. The alluvial succession of the Val di Chiana Basin includes two major unconformity-bounded units (Bettolle and Marciano Synthems in [45]) consisting of sand and mud accumulated by a southward-directed palaeodrainage. The Marciano Synthem is constrained to Calabrian by well-known mammal faunal associations [46].

The structural setting of the study area is defined by contractional structures related to the orogenesis of the Northern Apennines (i.e., fold-and-thrust system, [47] for a review) and by later structures related to the development of the Neogene-Quaternary basins ([37] for a review). Regarding the later ones, these were characterized by a prolonged activity from Late Serravallian to late Quaternary ([47] with references therein). The Pliocene-Pleistocene faults (Figure 2) controlled the configuration of the current structural depressions (i.e., Siena, Val di Chiana and Valdarno Basins) and their infill. In the study area (Figure 2), these faults can be categorized in three main systems depending on the age, the geometry and the kinematics: (i) Zanclean-Piacenzian N-S normal faults; (ii) Neogene-Quaternary NE-striking faults; and (iii) Neogene-Quaternary NW-striking faults. Zanclean N-S normal faults are mainly represented by the Rapolano Fault, a regional structure that bounds the eastern margin of the Siena Basin, partially covered by Piacenzian marine sediments $[48,49]$. It juxtaposes, in several places, the pre-Neogene succession of the Chianti- Cetona Mt. ridge (Tuscan Nappe, [50]) with the Zanclean-Piacenzian marine sediments filling the Siena Basin. Similar features characterize also minor faults associated to the Rapolano Fault (Figure 2). The maximum vertical offset of the Rapolano Fault was estimated in about $400 \mathrm{~m}$ on the basis of the interpretation of the seismic profiles [38]. Slickensides on minor faults mainly affecting the pre-Neogene Jurassic carbonate and siliceous units indicate a dominant dip-slip movement with minor left-lateral component. These faults are interrupted by NE- and NW-striking faults. These latter ones dissect the Piacenzian marine sediments and Late Pleistocene-Holocene travertine deposits [51-53], supporting the hypothesis of active tectonicsin the whole area. This is also confirmed by the prehistoric and historical seismicity mainly recorded by the travertine deposits $[53,54]$. Furthermore, NE- and NW-striking faults play a role in controlling the geothermal fluid circulation, as well as the location of thermal springs and travertine deposits [55-57]. These faults controlled also the late geomorphological evolution of the study area, mainly characterized by the Ambra Valley and Sentino Basin. In particular, the Ambra Valley area was mostly controlled by NE-striking fault system that is part of the so-called "ArbiaValmarecchia Line" ([58] with references therein). This consists of a brittle shear zone characterized by anastomosed fault segments [52], which interfered with the continental sedimentation during the Quaternary [22]. The Sentino Basin developed in response of the activation of several NW- and NE-trending faults. Their interplay gave rise to the peculiar zig-zag shaped structural depression, controlling the continental sedimentation as illustrated in the next paragraph. Both NW- and NE-striking faults are characterized by a dominant left- and right-lateral oblique-slip kinematics.

\section{Materials and Methods}

The stratigraphy and most of the structural data from sector 1 and the northern part of sector 2 were investigated in previous studies [22], which outlined the occurrence of an incised valley in the northern margin of the Siena basin. The evidence was integrated with new sedimentological and structural data obtained expanding the study area toward the south and including field activities in sector 3 and in the southern part of sector 2 . 
The spatial extent of the studied deposits was mapped on a 1:10,000 scale topographic base (Figures 5 and 6). The sedimentary units were characterized and ascribed to specific depositional environments following basin principles of facies analyses. The main palaeodrainage routes were calculated from palaeocurrent measurements, which were obtained from dip of foresets from cross-bedded strata and $a(t) b(i)$ clast imbrications.

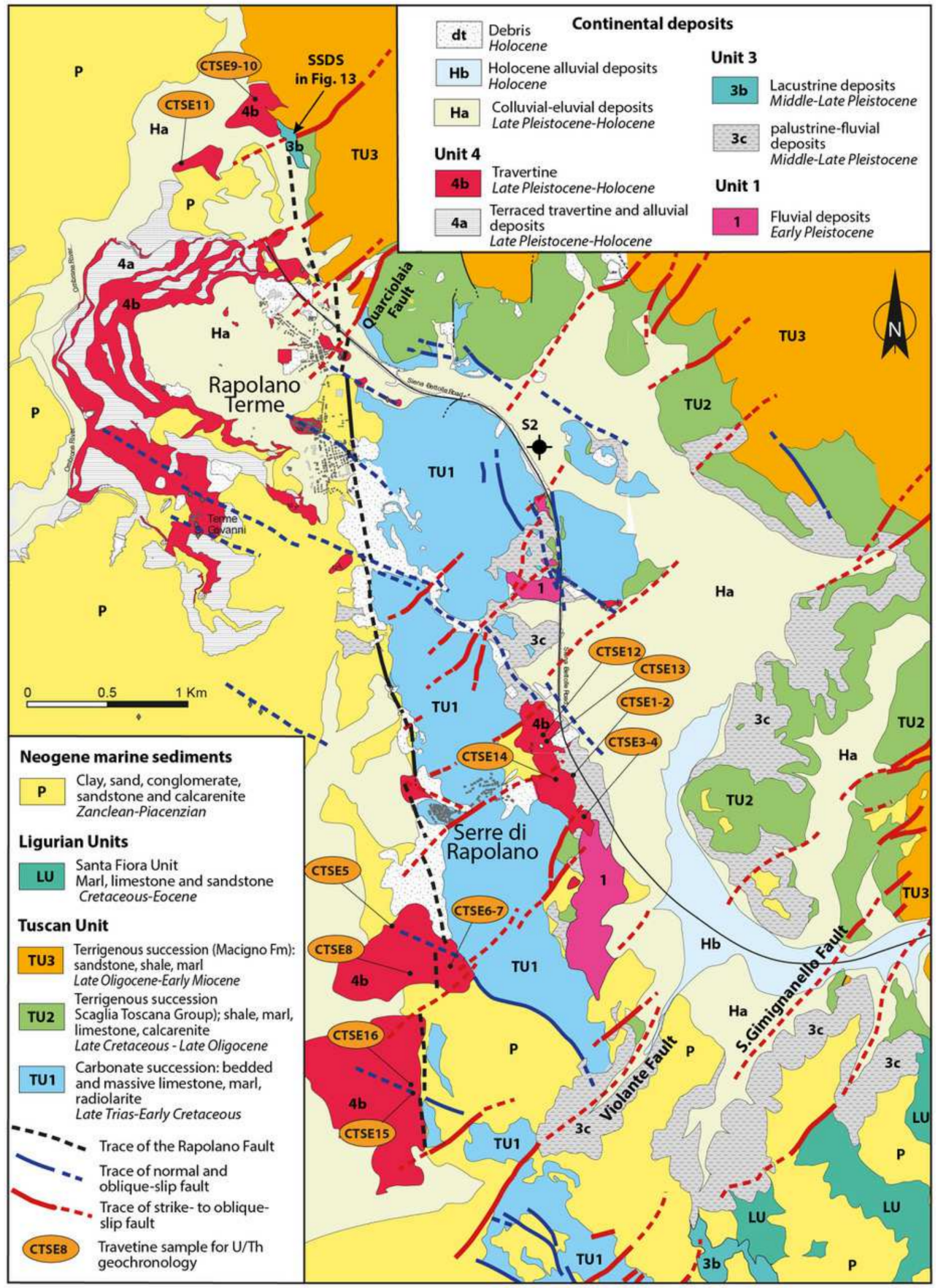

Figure 5. Geological map of the Sentino Basin (after [58], improved and expanded toward south). Querciolaia Fault corresponds to the F2 mentioned in the text and indicated in Figure 2; Violante and San Gimignanello Faults correspond to the F3 mentioned in the text and indicated in Figure 2. 


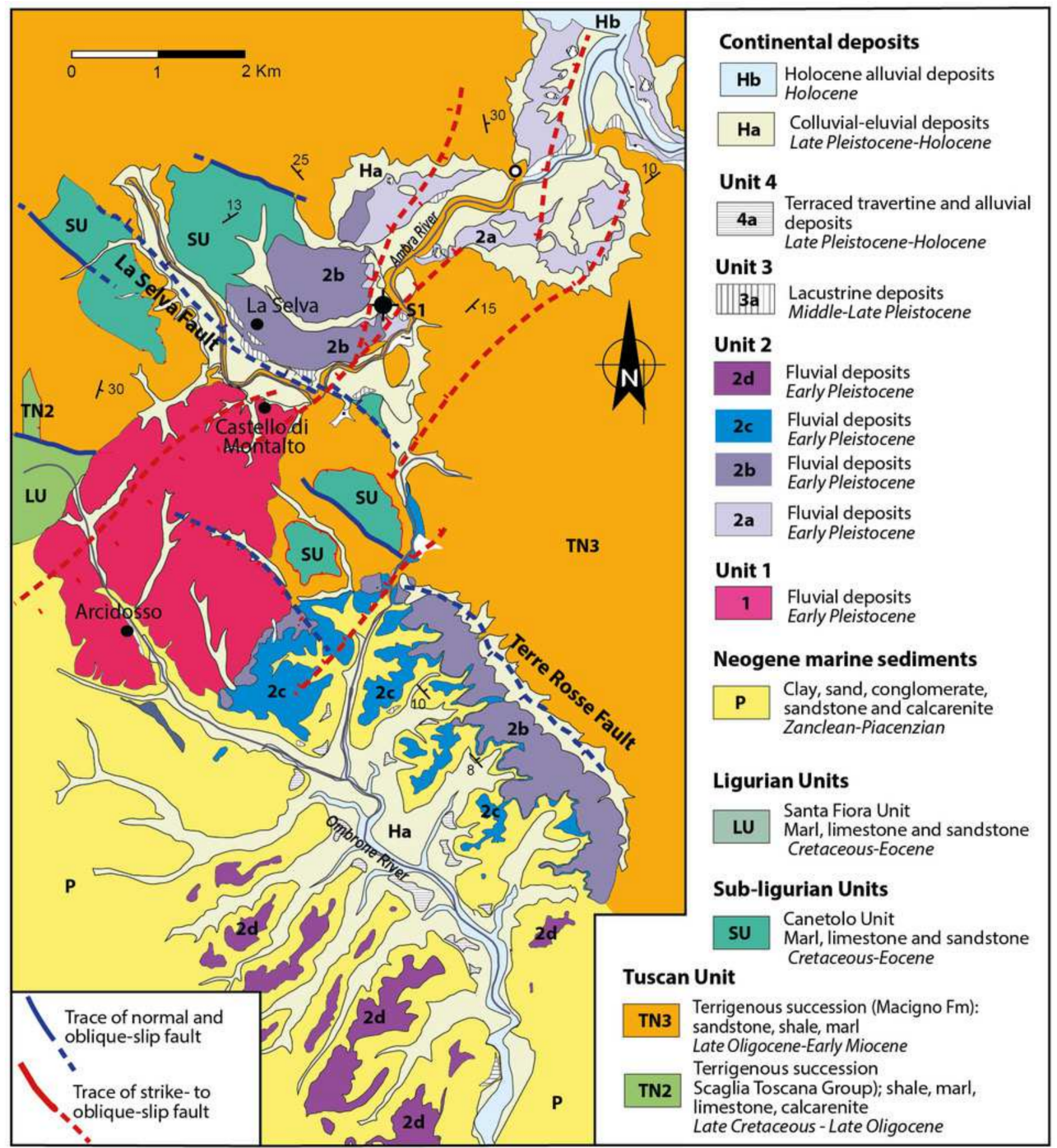

Figure 6. Geological map of the Ambra Valley (from [38], modified). La Selva Fault corresponds to the F1 mentioned in the text and indicated in Figures 2 and 3.

Structural analyses were focused on high-angle normal faults, which are thought to represent the youngest regional structures affecting both unconsolidated PliocenePleistocene deposits and pre-Neogene bedrock. Structural and kinematic data represent discrete clusters (structural stations), along exposed meso-fault surfaces.

U-Th dating was carried out for travertines exposed in the southern part of the study area (Figure 5). The dating procedure was conducted at the High-Precision Mass Spectrometry and Environment Change Laboratory (HISPEC), Department of Geosciences, National Taiwan University $[59,60]$ following the procedure already described in [53]. Determinations of all U-Th isotopic compositions and concentrations were made on a Thermo-Finnigan NEPTUNE multicollector inductively coupled plasma mass spectrometer (MC-ICPMS) [59]. Off-line data reduction methods followed [61]. Half-lives of U-Th nuclides used for age calculation was given by [62]. Isotopic and age errors given are two standard deviations of the mean and two standard deviations, respectively, unless otherwise noted.

Well logs and geophysical data reported by [22] were integrated with field evidence and a new borehole dataset in sector 3, in order to estimate thickness variability of the studied sedimentary entities, with particular focus on definition of the valley floor depth.

The studied deposits form a 1 to 3-km-wide and ca. 40-km-long entity, which crossed the three major sectors forming the study area. The succession was divided into four units, 
which are separated by erosional surfaces of abrupt changes in facies assemblages (e.g., change from fluvial to lacustrine deposits).

\section{Results}

\subsection{Structural Features}

Structural features are described for each sector indicated in Figure 3. Sector 1 (Figures 2 and 6) is part of the main brittle shear zone corresponding with the ArbiaValmarecchia shear zone (Figure 2, cf. [63]). This is mainly characterized by dominant NE-striking fault segments that are linked by NW-striking ones (Figure 4). Fault 1 (La Selva Fault, Figure 4) is part of this fault system. N-S- striking faults pre-date the NWand NE-striking ones, as indicated by their cross-cutting relationships. These faults affected only the bedrock mainly represented by Late Oligocene-Early Miocene sandstone (Macigno Fm), whereas NE- and NW-striking faults affected both the fluvial deposits and the bedrock (cf. [22,62]). Faults in bedrock are characterized by centimetre-thick core zones and damage zones wide up to $5 \mathrm{~m}$; meso-faults display well-developed sets of fractures, often with a en-echelon geometry concentrated near the slip surface. These characteristics weakened large volumes of rock, creating greater erodibility along the NE and NW fault trend. This process, enhanced by the hydrogeological pattern, favored the development of interconnected valleys mainly parallel to the NE-striking faults. The offset of these surfaces does not exceed a few meters. N-S, NE- and NW-striking fault planes show a number of kinematic indicators consisting of mechanical striation and calcite fiber-steps. In the damaged zones, arrays of extensional jogs and T-fractures mainly occur. Kinematics of $\mathrm{N}-\mathrm{S}$ striking faults indicate a dominant normal displacement. NE- and NW-striking faults (Figure 7) are characterized by dominant left-lateral oblique-slip movements. A synthesis of the collected data is reported in Figure 8.
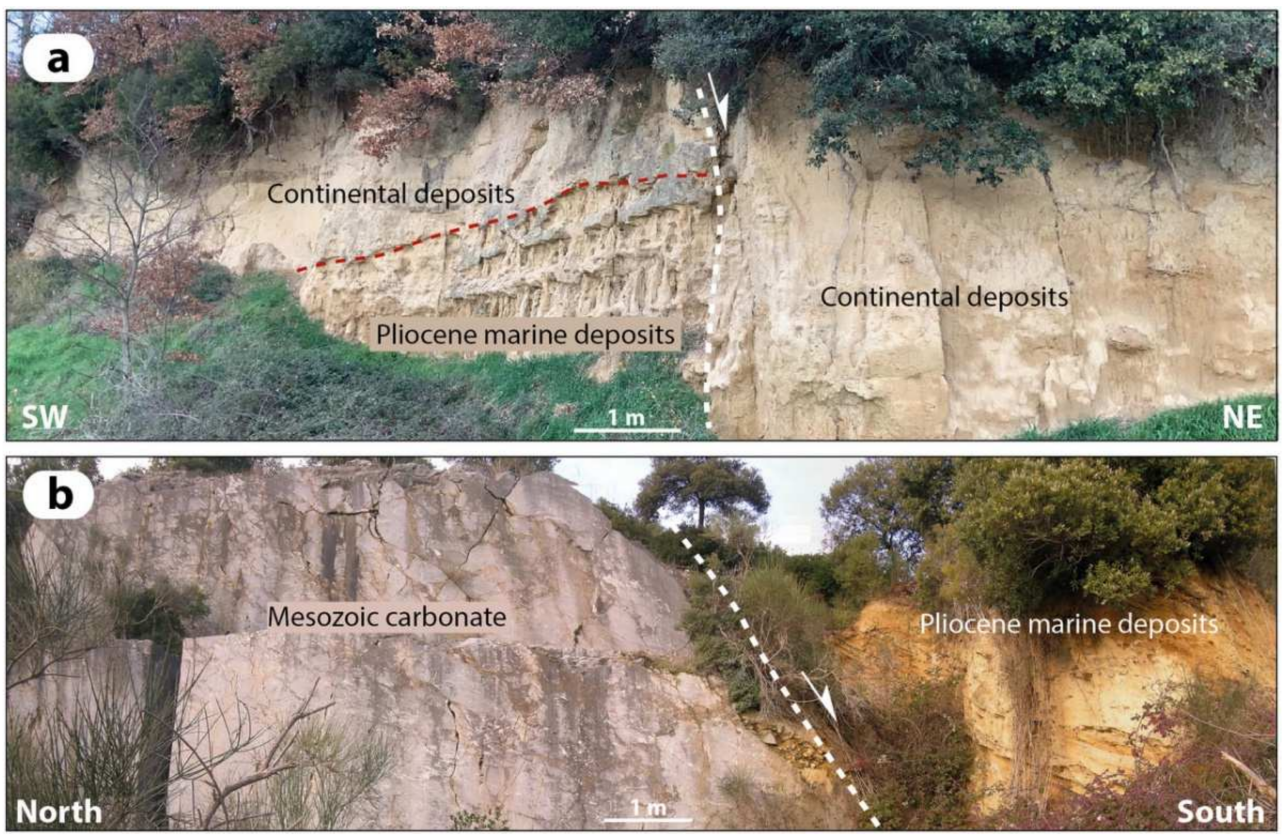

Figure 7. Panoramic view of faults affecting the successions filling the Sentino Basin and surroundings: (a) NW-striking normal fault dissecting Late Pleistocene continental sediments; (b) NE-striking left-lateral oblique-slip fault juxtaposing Piacenzian marine deposits to Mesozoic carbonate. 

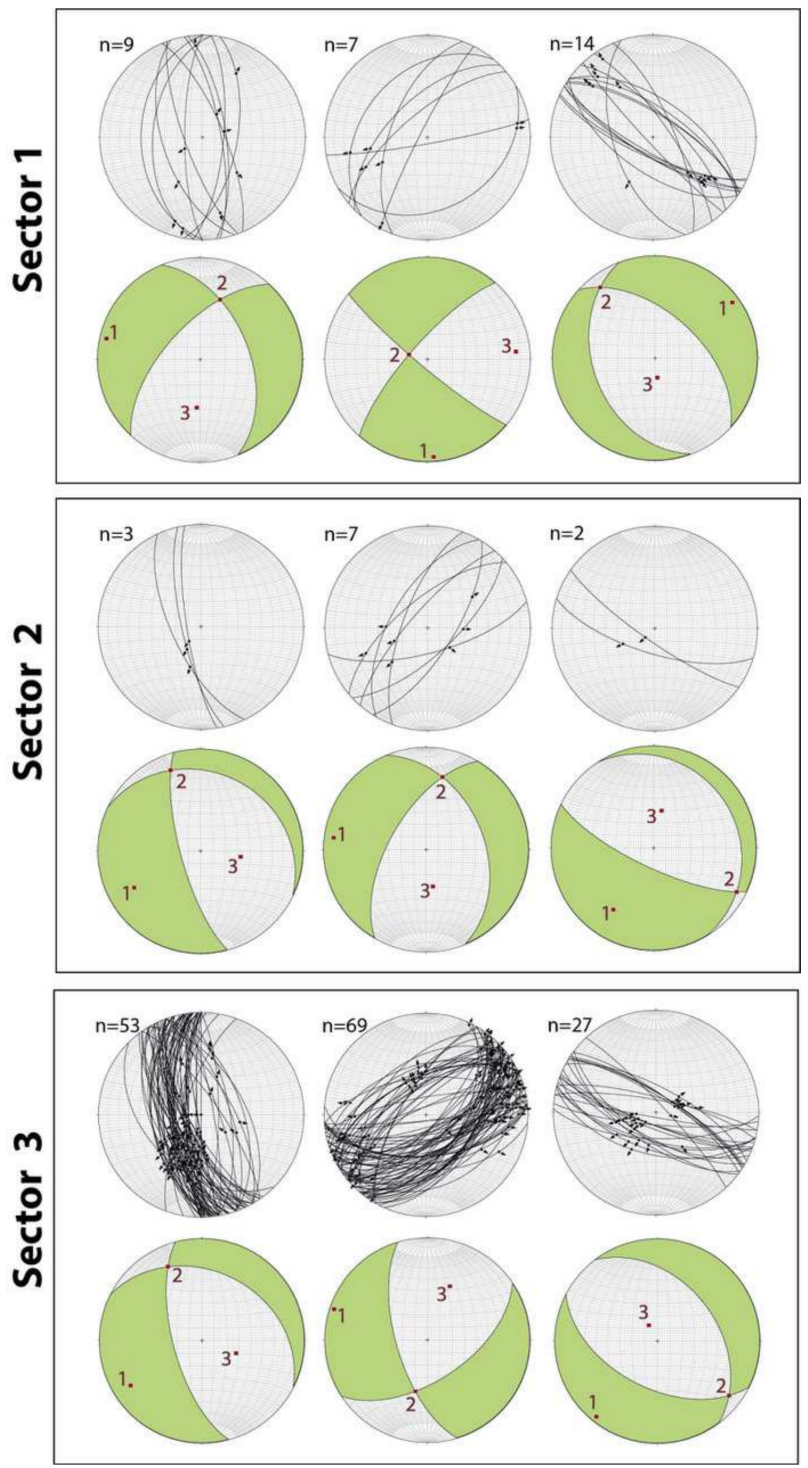

Figure 8. Stereographic diagrams (equiareal diagrams, lower hemisphere) illustrating cumulative kinematic data collected in different structural stations and divided per fault systems: N-S, NWand NE-striking faults. For each fault system, faults and striae (upper diagrams) and fault plane solutions diagrams with kinematic axes from the inversion of kinematic data are shown. Location of the indicated sectors are reported in Figure 3. Kinematics data from area 1 have been integrated with those published in [38]; Kinematics data from area 3 have been integrated with those published in [38].

Sector 2 (Figures 2, 5 and 6) is mainly defined by a main cartographic-scale fault named as the Terre Rosse Fault (Figure 6). It dips south-westward and it delimits, for at least $3 \mathrm{~km}$, the easternmost Pliocene sediments filling the Siena Basin from the bedrock composed of the Macigno Fm. The fault trace is buried by Quaternary deposits, denying direct observation and kinematic analyses on the main fault surface. Its maximum offset can be estimated at several tens of meters. The Terre Rosse Fault is interrupted to the northwest by the NE-striking fault. Kinematics analyses on minor structures in the footwall allow to recognise three fault systems, similarly to the Area 1: N-S, NW- and NE-striking (Figure 8). All faults show dominant normal to oblique-slip movements. (Figure 8).

Sector 3 (Figures 2 and 5) includes several cartographic scale faults (Figure 2). The most important ones bound the Sector 3, namely the Querciolaia Fault (F2 Fault in Figure 2) and Violante-Sangimignanello faults (F3 Fault in Figure 2) both NE-striking (Figures 2 and 6). 
These are characterized by fault traces exceeding $1 \mathrm{~km}$, by several tens of meters off-sets and they are associated with contemporaneous NW-striking faults (Figure 6). Both NWand NE-striking faults were recognised affecting the bedrock, represented by JurassicCretaceous carbonate succession, Cretaceous-Early Miocene shale/carbonate succession and the Pliocene-Quaternary deposits (cf. [50]). Faults in bedrock are characterized by centimetre-thick core zones and damage zones wide up to $20 \mathrm{~m}$; meso-faults display sets of fractures and a number of kinematic indicators, mainly consisting of mechanical striation and calcite or quartz fiber-steps. All faults show dominant normal to oblique-slip movements (Figure 8). NE- and SW-striking faults dissected the N-S striking Rapolano Fault, which activity was from Zanclean to Piacenzian [38].

\subsection{Stratigraphy}

The stratigraphy of the studied area is summarized in Figure 9, by means of an idealized cross-section along the valley axis.

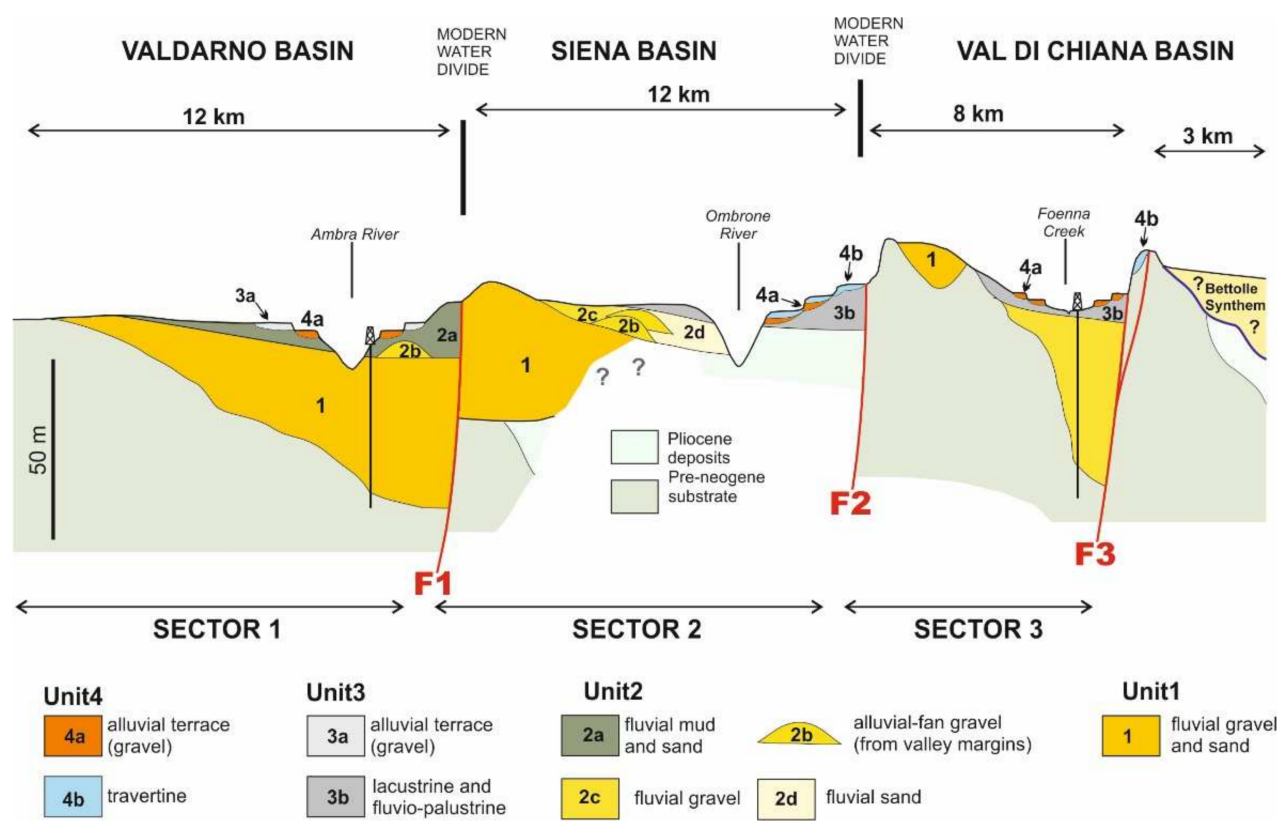

Figure 9. Schematic cross section along the axis of the study sedimentary body.

\subsubsection{Unit 1}

Sector 1

Sector 1 is characterized by a widespread cover of Holocene deposits (Figure 6). Deposits of Unit 1 do not occur in the most proximal reach of the sector 1, where preNeogene bedrock is exposed in the thalweg of the modern Ambra River, but borehole and geophysical data [22] show that 60-m-thick gravels occur just upstream of the fault F1 at the bottom of the modern valley (Figures 9 and 10). These gravelly deposits are confined in a $0.8-1.5 \mathrm{~km}$ wide palaeovalley (unit V1 in [22]; unit Q and FL in [64]), which wanders with an overall NNE-SSW trend and it cut the pre-Neogene bedrock. In the southernmost part of the sector 1, these deposits are locally exposed, and they consist of amalgamated and poorly-organized pebble to cobbles with scattered boulders. 


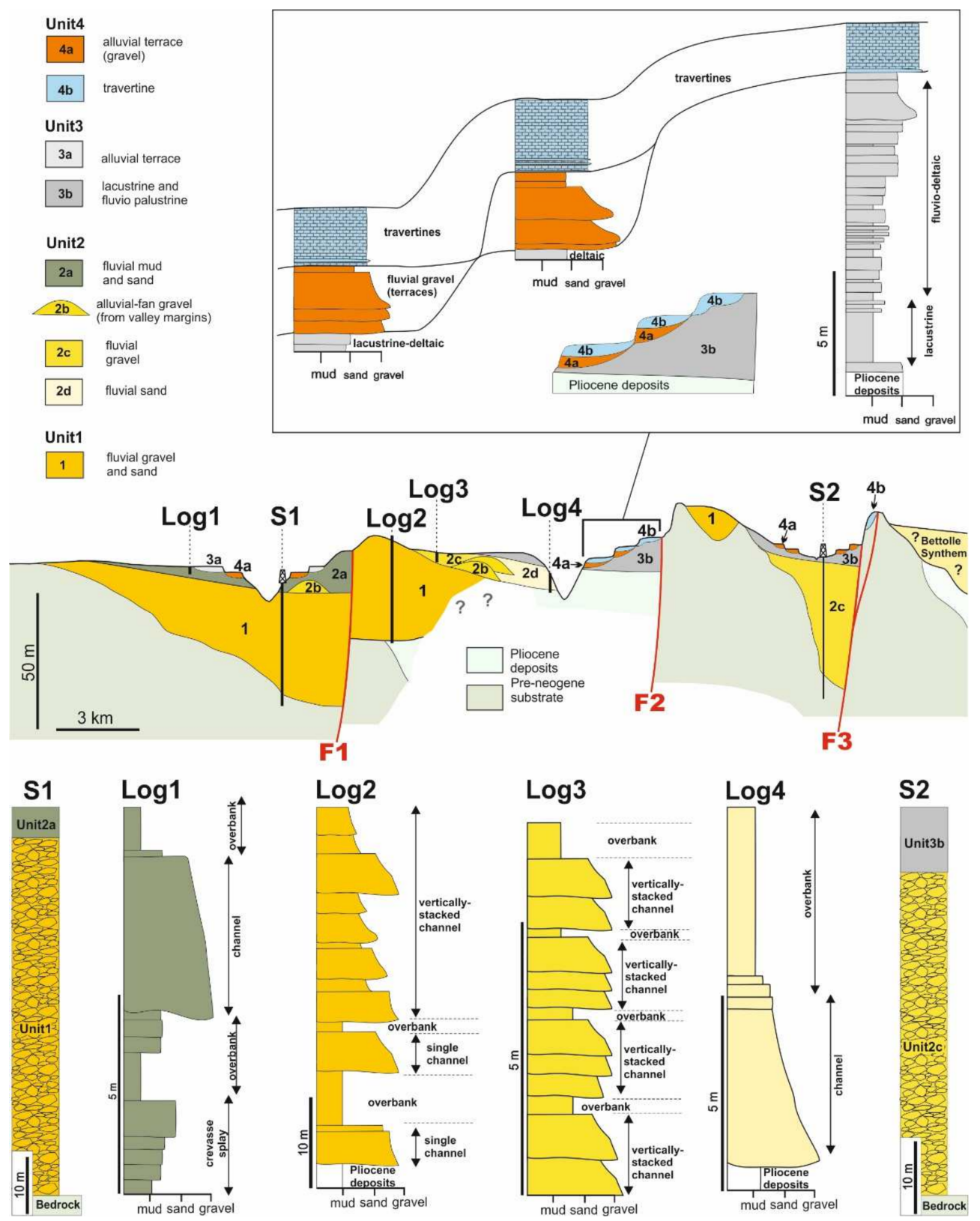

Figure 10. Simplified sedimentological logs and core data from the study deposits. Their location in the idealized longitudinal cross section shown in Figure 9 is shown.

Sector 2

Deposits of Unit 1 (unit V1 in [22]; unit Q and FL in [64]) are largely exposed in the northern part of the sector 2 (Figures 9, 10 and 11A). In the Castello di Montalto area, they cut the pre-Neogene bedrock, forming a sedimentary body wide ca $1.2 \mathrm{~km}$ and thick 60 to $70 \mathrm{~m}$. In the Arcidosso area, they cut the Pliocene marine deposits and they show a similar thickness but increased width to ca $2.5 \mathrm{~km}$. These deposits consist of gravels with subordinate sand and mud. Gravels consist of multilaterally arranged channelized bodies, which are up to $4.5-\mathrm{m}$ thick and several tens of meters wide in sections perpendicular to the palaeoflow direction (Figure 11A). Gravels form large-scale inclined beds, which are mainly made of clast-supported pebbles and sandy pebbles. Pebbly beds are up to 50-cm thick and they show a well-developed plane-parallel to planar-cross stratification, which is commonly highlighted by alternation of matrix-free and matrix-rich strata. Sandstone pebbles and cobbles from the Macigno Fm are deeply weathered. Channelized sandy deposits are less common, and they mainly occur in the upper part of the unit in the sector 2 . Sand beds 
are normally graded, erosively based and they exhibit plane parallel-stratification and ripple cross-lamination. Massive overbank mud is exposed in the proximal reach of the sector 2 (Figure 11A). These muds draped the whole valley and they are up to 5-6 m thick. They include organic-rich layers and pedogenic horizons with scattered root traces and carbonate concretions.
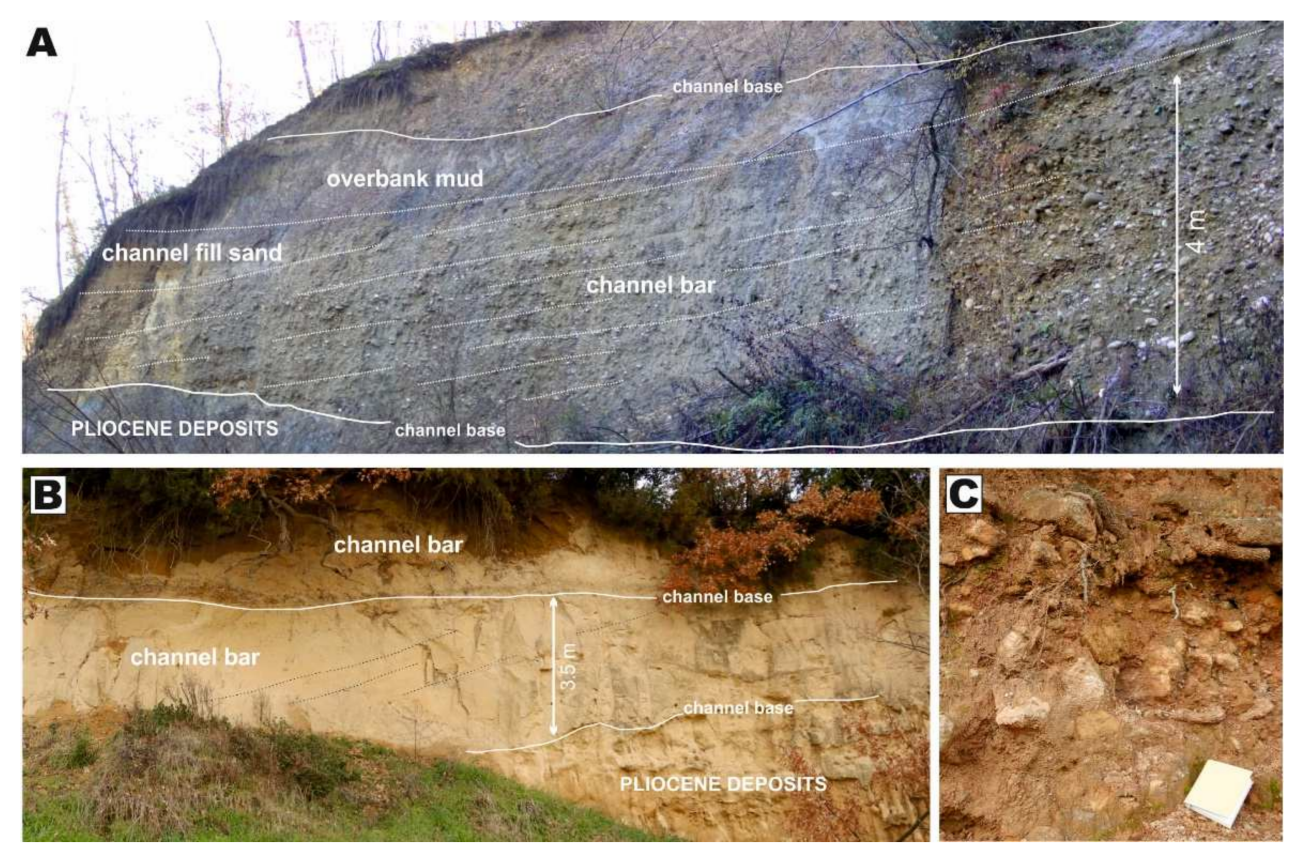

Figure 11. Unit 1 deposits. (A) Channelized gravel and overlying overbank mud exposed in the Arcidosso area. (B) Channelized sand overlying marine Pliocene deposits in the Sentino Basin area. (C) Poorly organized gravel in the Sentino Basin area.

Sector 3

Deposits of Unit 1 occurs in the sector 3 as an isolated, N-S trending lithosome overlying the pre-Neogene bedrock and Pliocene marine deposits in the east to Rapolano Terme. This sedimentary body is thick at least $20 \mathrm{~m}$ and it consists of clast-supported gravels grading southward into sand with subordinate gravels. Gravels occur above Mesozoic bedrock and they consist of moderately to well-rounded boulders of metric size? (Figure 11C). They are poorly organized exhibiting a gravelly to sandy matrix. Sandstone clasts from the Macigno Fm are deeply weathered, as those occurring in the sector 2 . Sandy deposits occur above Pliocene marine sand and they are 4-m-thick channelized bodies (Figure 11B). These bodies are made of medium-grained sand with sets of large-scale inclined beds dipping at 5 to $20^{\circ}$. Inclined beds are characterized by a plane parallel and ripple cross-lamination. These beds are floored by channel lag gravels, which include deeply weathered sandstone pebbles of the Macigno Fm.

\section{Palaeoflow Data}

In the sector 1, deposits of Unit 1 are not exposed, but subsurface investigations show that they are enclosed in a N-S trending depression up to a few hundred meters wide (Figure 5). In the sector 2, deposits of Unit 2 form a N-S trending, elongated body that bends eastward, where alluvial deposits overlie Pliocene sediments. Palaeoflow of these deposits (Figure 12) is consistent with the orientation of the elongated body and it changes from southward to eastward, where the studied deposits cover the Pliocene sediments. In the sector 3, Unit 1 forms a N-S trending body and the palaeoflow is directed southward in both gravelly and sandy facies. 


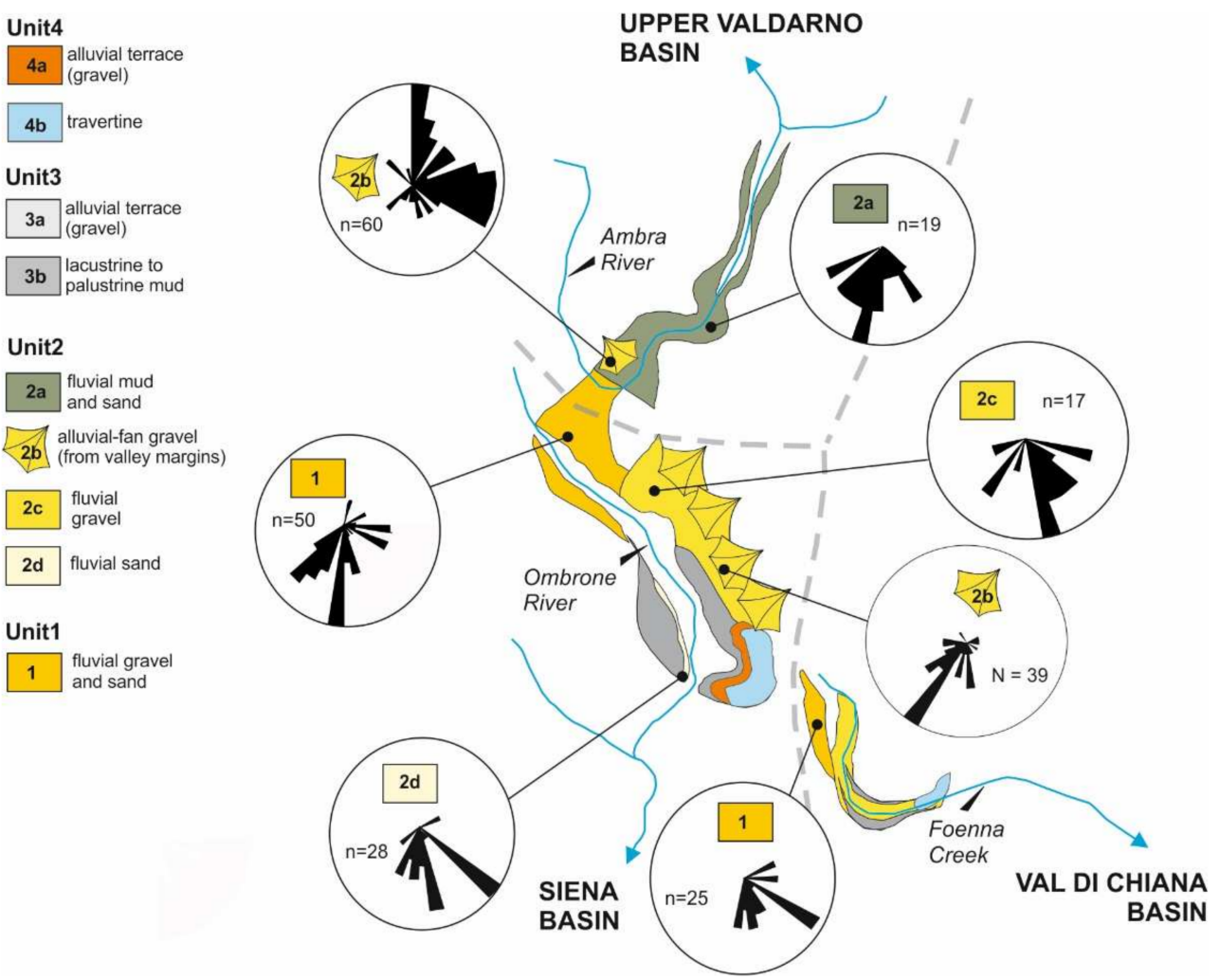

Figure 12. Paleocurrents distribution within the study deposits. Grey dashed line represents the watershed displayed in Figure 3.

Age

Organic-rich portions of overbank mud exposed in the Arcidosso area bear gastropod shells, including terrestrial Pomatia elegans and Retinella sp. [64]. The age distribution of this fauna spans from the earliest Gelasian to the Recent [65]. Palaeomagnetic studies revealed that a reverse magnetic polarity turned into a normal one at ca $25 \mathrm{~m}$ from the base of the unit [23].

\subsubsection{Unit 2}

Sector 1

Deposits of Unit 2 are confined within the same elongated palaeovalley that encloses the Unit 1 gravels occurring on top of them. Unit 2 deposits consist of mud with subordinate sand (V2fla in [22]), and interfingers with pebble to cobble-sized gravel in La Selva area (V2af in [22]). Mud is grey to dark grey and it is bedded or form massive tabular strata (Figure 13A). Greyish mud contains root traces and commonly root-bioturbated, whereas dark-grey mud is significantly enriched in organic matter and plant debris. Mud includes sandy deposits, which form tabular or channelized bodies. Tabular bodies thick up to $1.5 \mathrm{~m}$ consist of massive to plane parallel-stratified, medium-grained to fine-grained sand. Channelized bodies are up to 4 to $5 \mathrm{~m}$ thick and at least 50 to $60 \mathrm{~m}$ wide alongstrike. Channelized sand consists of fining-upward bedsets of pebbly, coarse-grained sand grading into mud. These sandy bodies feature metric-scale inclined strata dipping at 5 to $10^{\circ}$. Inclined beds show plane parallel and trough cross-stratification and ripple cross-lamination. Gravels occurring in La Selva area consist of clast-supported, moderately to well-rounded, pebbles to boulders with subordinate sandy intercalations. Gravels form channelized units, up to 1.2-2 $\mathrm{m}$ thick. These units show an overall fining-upward trend and a range from massive at the base to crudely plane-parallel stratified at the top. In plain view, these gravels are organized in a fan shape, which has its apex on the eastern flank of the modern valley. 

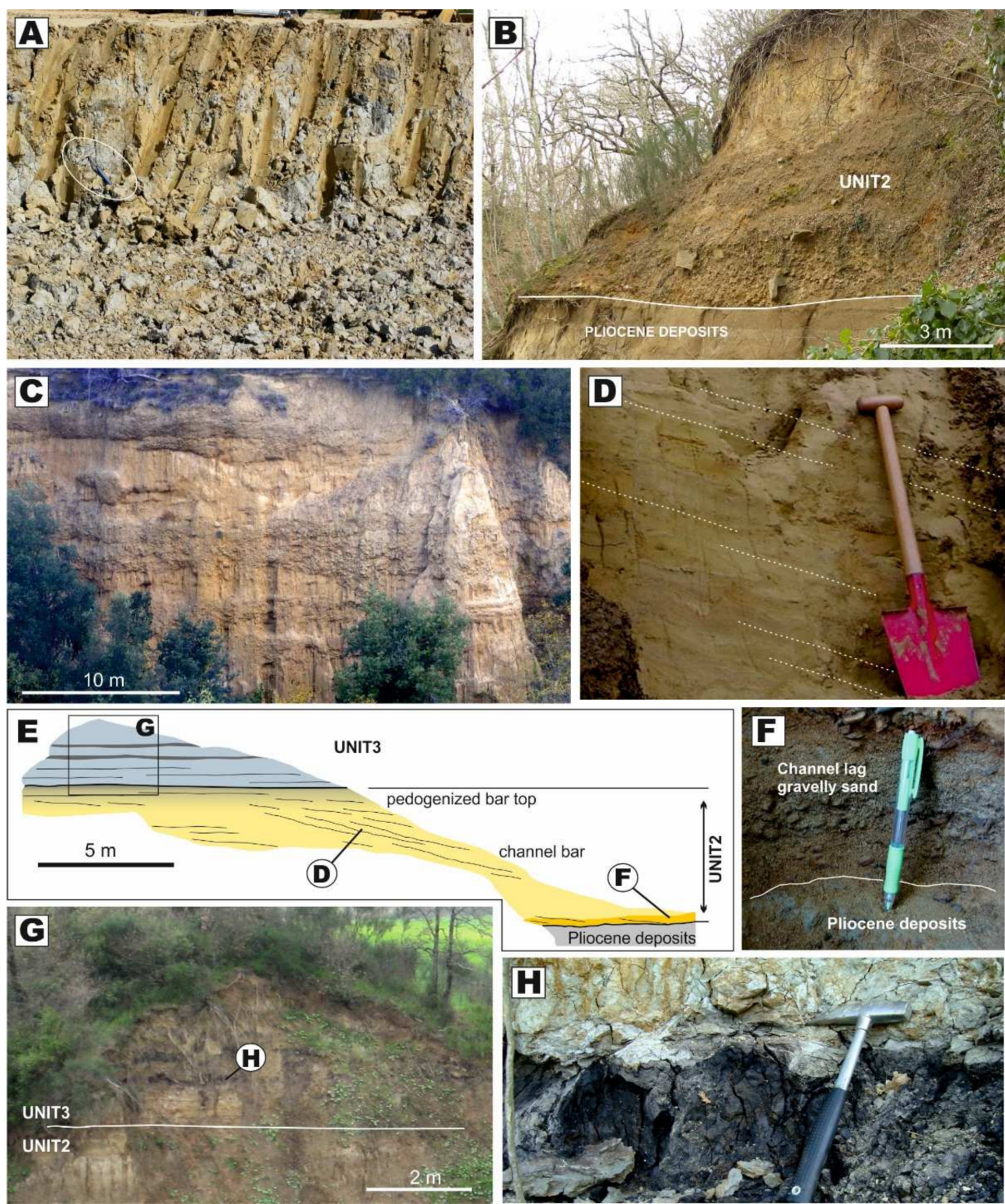

Figure 13. Deposits of Unit 2 and 3. (A) Massive overbank mud of Unit 2 exposed upstream of fault F1. (B) Fluvial gravels of Unit 2 overlying Pliocene marine deposits just downstream of fault F1. (C) Alluvial-fan gravel and sand (Unit 2) sourced from the bedrock forming the footwall block of Terre Rosse fault (Sector 2). (D) Sandy bar deposits (Unit 2) of the Pian di Bari area. (E) Scheme showing deposits of Units 2 and 3 in the Pian di Bari outcrop. (F) Fluvial gravelly sand of Unit 2 erosionally overlying Pliocene marine deposits. $(\mathbf{G}, \mathbf{H})$ Horizontally bedded palustrine deposits of Unit 3.

\section{Sector 2}

Deposits of Unit 2, are exposed in the northern part of sector 2 and consists of fluvial (V2flb in [22]) and alluvial fan (V2af in [22]) deposits. Fluvial deposits consist of gravels grading eastward into sand (Figure 13B) and are confined within a 2-2.5 $\mathrm{m}$ wide and N-S trending palaeovalley. Gravelly fluvial deposits are ca. $15 \mathrm{~m}$ thick and from 1 to $2 \mathrm{~m}$ thick, multi-storey channel bodies, commonly floored by $a(t) b(i)$-imbricated pebbles and scattered, angular boulder-sized clasts. Gravel ranges from plane-parallel to cross-stratified. Fluvial sand is characterized by multilateral channel bodies up to 5-6 $\mathrm{m}$ thick (Figure 13E). These bodies are made of medium-grained sand floored by fine pebbles (Figure 13F), which grade upward into pedogenized fine-grained sand and mud. Channelized sand is 
structured into sets of large-scale inclined beds dipping at 5 to $20^{\circ}$ (Figure 13D). Inclined beds are characterized by a plane parallel, trough cross-stratification and ripple crosslamination. The overlying mud displays evidence of pedogenesis. Alluvial-fan de-posits are sited along the eastern side of the palaeovalley and are sourced by the relief generated by the Terre Rosse Fault. Alluvial-fan deposits mainly consist of pedogenized sand that passes upward into channelized gravels (Figure 13C). Sandy deposits consist of vertically stacked, tabular beds which range from massive to slightly plane-parallel stratified. Channelized gravels are commonly floored by $a(t) b(i)$-imbricated cobbles with pebbles organized in plane-parallel to cross-stratification.

Sector 3

Deposits of Unit 2 do not occur in the eastward reach of the sector 3, where preNeogene bedrock crops out in the thalweg of the Foenna Creek. The western part of the sector 3 (i.e., Sentino Basin) is characterized by a widespread cover of Holocene deposits (Figure 5), but evidence for the occurrence of unit 2 arise from new borehole data (Figure 10). These data show that in this area the Unit 2 occurs below the Holocene alluvium of the Foenna Creek and consists of ca. $60 \mathrm{~m}$ thick gravel and sand.

\section{Palaeoflow Data}

Palaeocurrents from fluvial deposits in the sectors 1 and 2 point to an overall palaeoflow directed toward south (Figure 12). Alluvial-fan systems are associated with transverse supplies, which derive from west and east in the sector 1 and 2, respectively. No evidence of palaeoflow direction can be detected in the sector 3, since Unit 2 deposits have only been detected in the subsurface.

Age

No age constraints exist for deposits forming this unit.

\subsubsection{Unit 3}

Sector 1

The Unit 3 in sector 1 is represented by alluvial terraces of the Ambra River (Figure 6). These deposits are up to $2 \mathrm{~m}$ thick and are largely covered by Holocene colluvium. They mainly consist of channelizes sand covering a gravelly lag.

\section{Sector 2}

The Unit 3 is up to $15 \mathrm{~m}$ thick and it mainly occurs in the southern part of the sector. It is mainly represented by lacustrine and palustrine mud, with subordinate sandy intercalation, which are locally common in the upper part of the unit. In the Pian di Bari area, it is a few meters thick and cover overbank mud of Unit 2 (Figure 13E,G). In this area, it consists of palustrine, organic-rich mud (Figure $13 \mathrm{H}$ ) with sandy intercalations containing abundant freshwater molluscs. In the southernmost part of the sector 2, the Unit 3 uncomfortably overlays Pliocene marine deposits and it consists of lacustrine mud grading upward into deltaic sandy beds. Lacustrine mud is tightly laminated including layers of well-sorted fine sand. These lacustrine layers are intensely deformed by dewatering structures and they are cut by syn-sedimentary normal faults (Figure 14). Overlying deltaic sandy beds are mainly tabular and characterized by widespread plane-parallel stratifications. Locally, they 0.5 to $1.5 \mathrm{~m}$ thick channelized bodies, which are paved by gravelly lags; they developed as distributary channels of small-scale deltaic systems locally sourced from the Rapolano Terme area. In the southernmost part of the sector 2, the flat morphological surface capping the lacustrine deposits defines a N-S oriented flange, that is ca. $6 \mathrm{~km}$ long and $0.5-1.5 \mathrm{~km} \mathrm{~m}$ wide. Such a flange is currently drained by the southward-flowing Bestina Creek, a 1-2 m wide rill that has been reclaimed by agricultural activities. No outcrops occur along the creek, but the modern soil flooring the flange includes abundant gravelly deposits. 

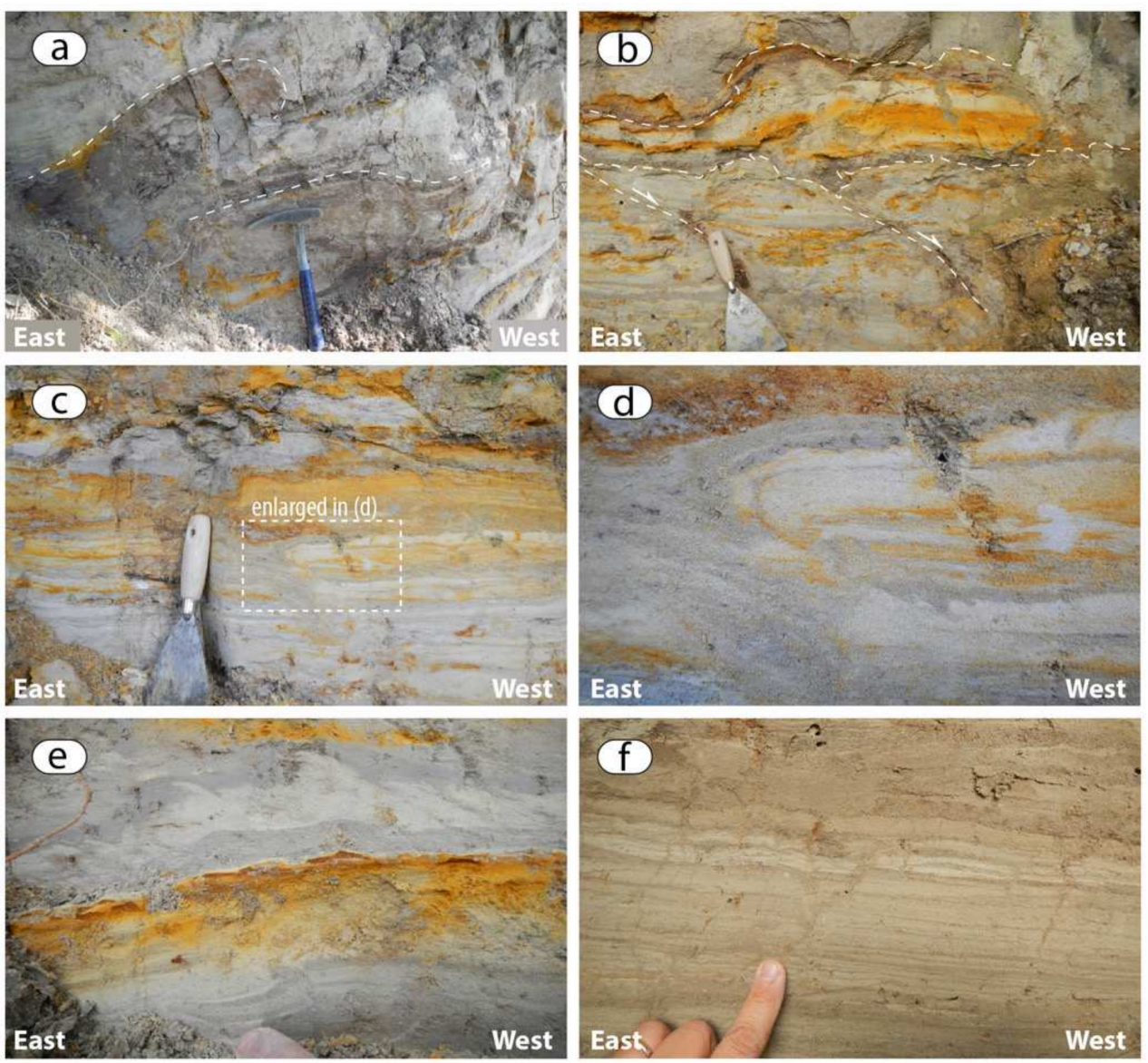

Figure 14. Soft-sediment deformation structures in lacustrine sandy silt (Unit 5b); (a) detached highly-non cylindrical fold; (b) shear bands and related deformed laminations; (c,d) slump sheets; (e) slump sheets and deformed laminations; (f) clastic dykes.

Sector 3

In this sector, Unit 3 is up to $25-30 \mathrm{~m}$ thick but is poorly exposed. It mainly consists of mud with subordinate sands. Muddy deposits are massive, with organic-rich layers and local evidence of pedogenic processes (e.g., caliche). Sandy layers are up to $1.5 \mathrm{~m}$ thick and they show erosive bases floored by fine-grained gravels. The geometry of these sandy bodies cannot be defined because of paucity of outcrops.

\section{Palaeoflow Data}

In sector 1, the Unit 3 is represented by terraced deposits of the Ambra River, indicating a northward-directed palaeoflow, in agreement with the course of the modern Ambra River. In sectors 2 and 3, no palaeoflow data are available for Unit 3 deposits mainly due to their fine-grained nature and paucity of exposures.

Age

No age constraints have been detected for the deposits forming this unit.

\subsubsection{Unit 4}

Sector 1

Unit 4 in sector 1 is represented by alluvial terraces of the Ambra River (Figure 6). These consists of are 1-2 m thick sand and are largely covered by Holocene colluvium, which prevents from a detailed description. A precise boundary between terraces of Unit 3 and 4 cannot be defined. 
Sector 2

The area is characterized by the presence of thick successions (up to $50 \mathrm{~m}$ ) of continental carbonates (Figure 15A,C) and subordinate fluvial terraces (Figure 15B). These carbonates (mostly travertine, secondarily calcareous tufa and lacustrine deposits [55]) are widely diffused along all the basin margins (Figure 5). They were dated through U-Th isotopic composition (cf. $[66,67]$ ) and originated from several thermal springs in the area $[68,69]$. Facies association [51-56,70-75] evidences a large variability in their depositional environments, generally evolving from proximal systems (typically close to vents, like mounds and fissure ridges), to intermedi-ate (slopes and channels) up to distal (marsh, shallow lakes and transitional to alluvial plains) [76]. Local sections show the direct superposition of the carbonates to alluvial/fluvial clastic deposits (Figure 10). In some areas, the carbonate deposits are arranged in different quotes corresponding to at least three depositional terraces (Figure 10).
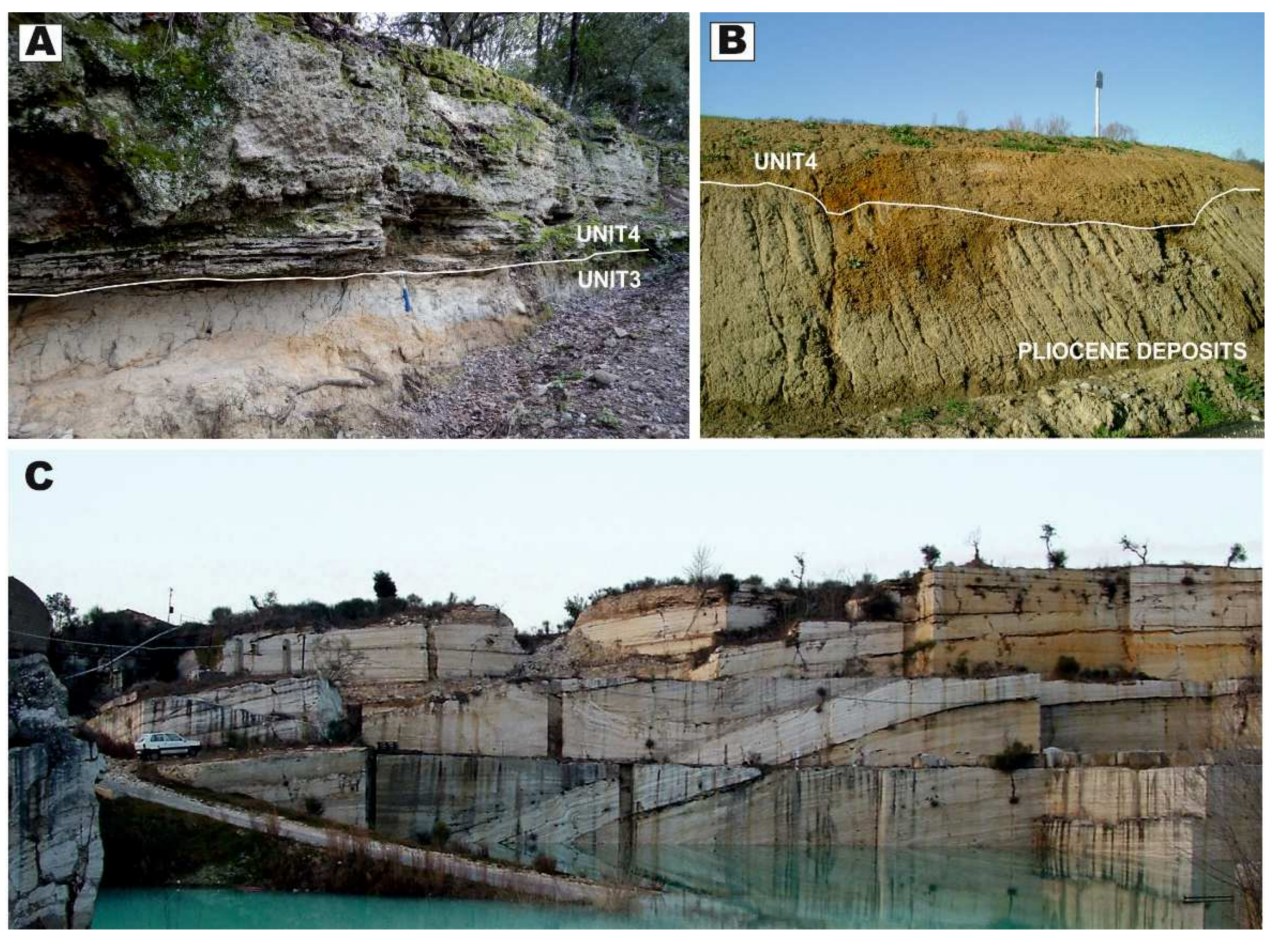

Figure 15. Deposits of Units 3 and 4. (A) Travertine of Unit 3 unconformably overlying lacustrine sand of Unit 3. (B) Fluvial terraces of the Ombrone River (Unit 4) covering Pliocene marine mud. (C) Travertines of Unit 4 in the Rapolano area.

Sector 3

Differently to Sector 2, the Sector 3 shows a patchy distribution of the continental carbonates (dominantly travertine) deposited in similar depositional environments, but with reduced extent (Figure 5) and thickness (up to $15 \mathrm{~m}$ ). Also in this sector, travertines rest on fluvial/alluvial deposits (sands and conglomerates) and they evidence a distribution in at least three depositional terraces.

\section{Palaeoflow Data}

The alluvial deposits belonging to Unit 4 were accumulated by a drainage system configured similarly to that one of the present-day drainage. Likewise, the travertine deposition shows a dominant W-SW direction in the Sector 2 (from the basinal shoulder towards the Ombrone River hydrographical pattern) and an E-SE direction in the Sector 3 (towards the Sentino Basin and Foenna Creek) 
Age

Sixteen travertine samples were collected in the area for radiometric analysis (Table 1 and Figure 16). All samples derived from macrocrystalline low porous material, avoiding the presence of secondary cements.

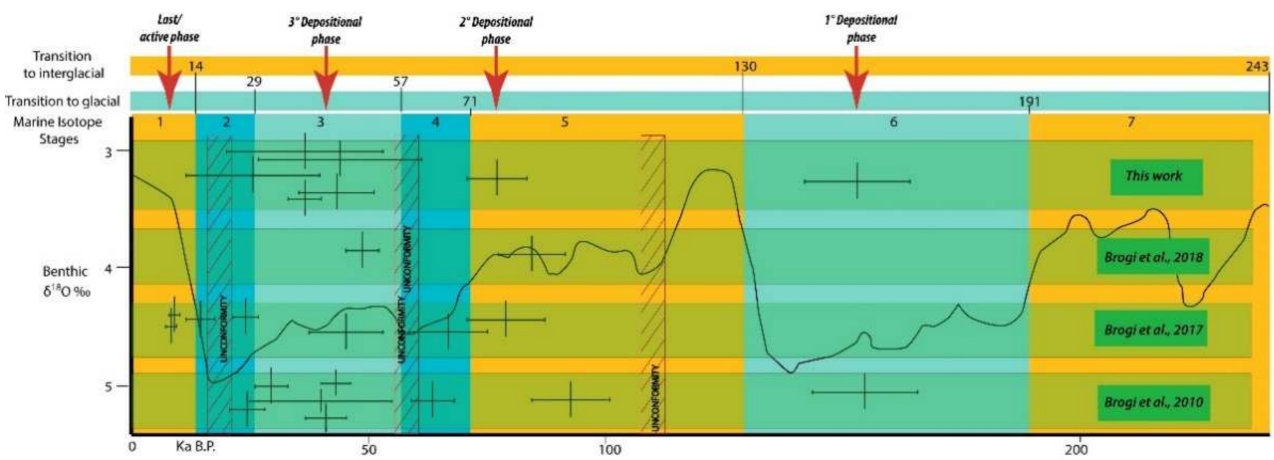

Figure 16. Comparison between available paleoclimate and travertine data of Rapolano Terme area. The new radiometric data here achieved (first line) are compared with previous ones $[51,53,54]$ and recognized unconformities. Travertine data are reported with their standard deviation. Black line is the SPECMAP marine paleoclimatic $\delta 18 \mathrm{O}$ record during late Pleistocene time [66]. It is evidenced the presence of at least three previous depositional phases. See text for details.

Due to different $\mathrm{U}$ and Th-concentrations, three samples resulted impossible to date, one not useful (infinite age error) and six samples with a very high error range. Combining the resulting data with stratigraphic and radiometric data, already published on the same travertine $[51,53,54,74]$, it is possible to evidence a cluster of four main depositional phases separated by unconformities and succeeding from the latest Middle Pleistocene up to now. 


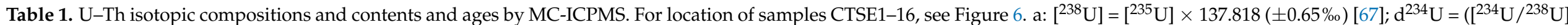

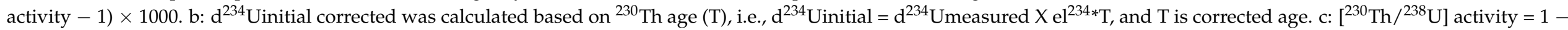

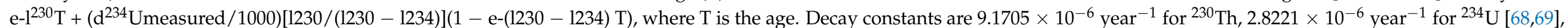

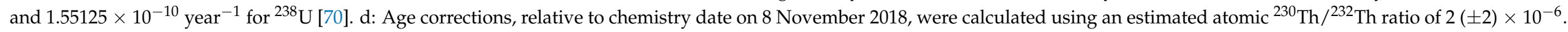

\begin{tabular}{|c|c|c|c|c|c|c|c|c|c|c|}
\hline $\begin{array}{l}\text { Sample } \\
\text { ID }\end{array}$ & $\begin{array}{c}\text { Weight } \\
\text { g }\end{array}$ & $\mathrm{ppb}^{238} \mathrm{U}$ & $\begin{array}{c}{ }^{232} \mathrm{Th} \\
\mathrm{ppt}\end{array}$ & $\begin{array}{c}\mathcal{\delta}^{234} \mathrm{U} \\
\text { Measured }^{\mathrm{a}}\end{array}$ & $\begin{array}{l}\left.{ }^{[230} \mathrm{Th} /{ }^{238} \mathrm{U}\right] \\
\text { Activity }\end{array}$ & $\begin{array}{c}{ }^{230} \mathrm{Th} /{ }^{232} \mathrm{Th} \\
\text { Atomic }\left(\times 10^{-6}\right)\end{array}$ & $\begin{array}{l}\text { Age (yr Ago) } \\
\text { Uncorrected }\end{array}$ & $\begin{array}{l}\text { Age (year Ago) } \\
\text { Corrected c,d }\end{array}$ & $\begin{array}{c}\text { Age (year BP) } \\
\text { Relative to } 1950 \mathrm{AD}\end{array}$ & $\begin{array}{c}\mathcal{\delta}^{234} U_{\text {initial }} \\
\text { Corrected }^{b}\end{array}$ \\
\hline CTSE-1 & 0.04874 & $35.054 \pm 0.075$ & $27,753 \pm 136$ & $362.3 \pm 6.2$ & $0.519 \pm 0.017$ & $10.82 \pm 0.35$ & $51,144 \pm 2069$ & $43,474 \pm 8222$ & $43,405 \pm 8222$ & $410 \pm 12$ \\
\hline CTSE-2 & 0.05378 & $94.70 \pm 0.18$ & $708,677 \pm 19,326$ & $194.1 \pm 3.4$ & $0.806 \pm 0.088$ & $1.78 \pm 0.20$ & $117,345 \pm 22,358$ & $-33,993-$ & $-34,062-$ & $176 \pm 94$ \\
\hline CTSE-3 & 0.05536 & $45.624 \pm 0.088$ & $173,796 \pm 2278$ & $299.6 \pm 4.9$ & $0.653 \pm 0.047$ & $2.83 \pm 0.20$ & $73,685 \pm 7309$ & $27,761 \pm 68,463$ & $27,692 \pm 68,463$ & $324 \pm 45$ \\
\hline CTSE-4 & 0.05735 & $34.005 \pm 0.067$ & $43,933 \pm 292$ & $340.2 \pm 5.1$ & $0.416 \pm 0.017$ & $5.31 \pm 0.23$ & $39,862 \pm 1997$ & $26,651 \pm 14,333$ & $26,583 \pm 14,333$ & $367 \pm 15$ \\
\hline CTSE-5 & 0.05517 & $4.611 \pm 0.019$ & $51,737 \pm 368$ & $71 \pm 23$ & $0.123 \pm 0.039$ & $0.181 \pm 0.057$ & $13,297 \pm 4496$ & 20,00 & - & - \\
\hline CTSE-6 & 0.07041 & $3.205 \pm 0.010$ & $8376 \pm 24$ & $312 \pm 22$ & $0.773 \pm 0.034$ & $4.88 \pm 0.22$ & $92,641 \pm 6725$ & $64,393 \pm 34,439$ & $64,324 \pm 34,439$ & $374 \pm 41$ \\
\hline CTSE-7 & 0.04816 & $16.914 \pm 0.049$ & $53,671 \pm 381$ & $248.5 \pm 7.8$ & $0.812 \pm 0.044$ & $4.22 \pm 0.23$ & $109,143 \pm 9762$ & $71,545 \pm 50,131$ & $71,477 \pm 50,131$ & $304 \pm 36$ \\
\hline CTSE-8 & 0.06769 & $45.21 \pm 0.11$ & $32,168 \pm 164$ & $427.8 \pm 5.6$ & $0.792 \pm 0.017$ & $18.35 \pm 0.39$ & $83,872 \pm 2582$ & $77,570 \pm 6962$ & $77,501 \pm 6962$ & $532 \pm 12$ \\
\hline CTSE-9 & 0.05669 & $10.124 \pm 0.029$ & $14,796 \pm 57$ & $292.8 \pm 9.9$ & $0.503 \pm 0.023$ & $5.68 \pm 0.26$ & $52,667 \pm 3085$ & $37,095 \pm 17,221$ & $37,026 \pm 17,221$ & $325 \pm 18$ \\
\hline CTSE-10 & 0.05010 & $36.926 \pm 0.064$ & $12,819 \pm 48$ & $612.3 \pm 6.3$ & $0.5119 \pm 0.0099$ & $24.31 \pm 0.48$ & $40,602 \pm 952$ & $37,841 \pm 2952$ & $37,772 \pm 2952$ & $681 \pm 9.0$ \\
\hline CTSE-11 & 0.16055 & $92.95 \pm 0.20$ & $130,077 \pm 1453$ & $248.4 \pm 3.9$ & $0.538 \pm 0.022$ & $6.34 \pm 0.27$ & $60,234 \pm 3249$ & $44,822 \pm 17,044$ & $44,753 \pm 17,044$ & $282 \pm 13$ \\
\hline CTSE-12 & 0.05824 & $41.637 \pm 0.081$ & $251,379 \pm 3270$ & $220.3 \pm 5.8$ & $1.079 \pm 0.057$ & $2.95 \pm 0.16$ & $204,833 \pm 30,052$ & $118,921 \pm 84,188$ & $118,852 \pm 84,188$ & $308 \pm 86$ \\
\hline CTSE-13 & 0.0938 & $37.936 \pm 0.064$ & $169,548 \pm 2313$ & $169.9 \pm 2.2$ & $1.304 \pm 0.062$ & $4.81 \pm 0.24$ & - & - & - & - \\
\hline CTSE-14 & 0.0529 & $49.854 \pm 0.089$ & $174,281 \pm 2521$ & $167.1 \pm 2.6$ & $1.194 \pm 0.063$ & $5.63 \pm 0.31$ & $393,522 \pm \infty$ & $356,719 \pm \infty$ & $356,649 \pm \infty$ & $457.1 \pm \infty$ \\
\hline CTSE-15 & 0.0708 & $30.408 \pm 0.058$ & $31,495 \pm 208$ & $154.3 \pm 2.8$ & $0.931 \pm 0.027$ & $14.82 \pm 0.44$ & $167,748 \pm 11,008$ & $156,134 \pm 15,886$ & $156,064 \pm 15,886$ & $239.7 \pm 11.6$ \\
\hline CTSE-16 & 0.0541 & $378.76 \pm 0.58$ & $921,367 \pm 32,039$ & $206.6 \pm 2.1$ & $0.731 \pm 0.043$ & $4.95 \pm 0.34$ & $97,950 \pm 9113$ & $68,881 \pm 35,800$ & $68,812 \pm 35,800$ & $250.9 \pm 22.3$ \\
\hline
\end{tabular}




\section{Discussion}

\subsection{Palaeo-Drainage Evolution and Age}

The confinement of the fluvial deposits along a narrow N-S trending depression, along with the dominance of palaeoflow parallel to the axis of this depression provide solid insights to confirm the occurrence of an ancient southward-draining valley in the study area [45]. This palaeovalley entered the western side of the Val di Chiana Basin in the Rigomagno area (Figure 2), where Gelasian to Calabrian valley-fill deposits were described [45].

The complex spatial distribution of the valley-fill deposits and the remarkable changes in their thickness, are characteristics explained here as a complex interplay between tectonics and sedimentation (Figure 17). The depositional history of this palaeovalley is reconstructed, with particular emphasis on the role played by the major faults (F1 to F3 in Figure 2) in controlling the aggradation and the avulsion of the related fluvial systems.
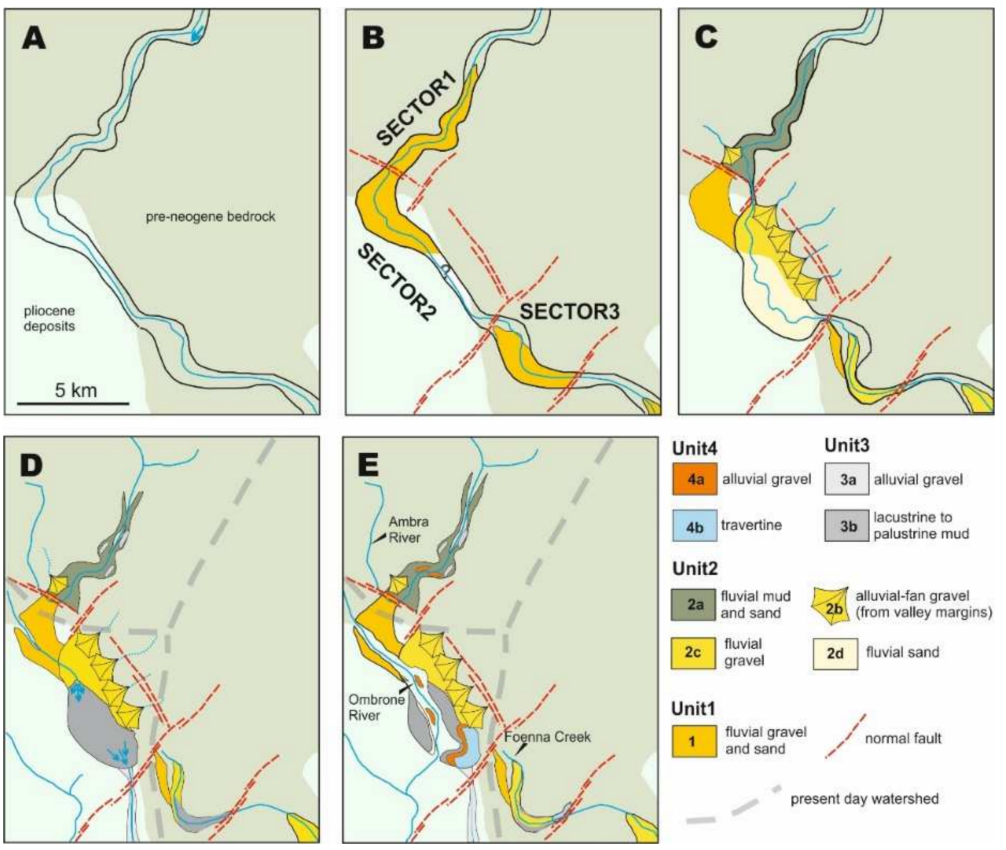

Figure 17. Reconstructed depositional evolution of the study valley.

The first evolutive stage was associated with an incision of the main valley system (Figure 17A), which assumed a different aspect ratio as function of the hosting substrate nature (i.e., pre-Neogene bedrock vs. Pliocene deposits). The first aggradational phase (Figure 17B) was especially pronounced at the outlet of the valley in the Siena Basin, where a 60-m-thick, gravel-dominated Unit 1 was emplaced (sectors 1 and 2). Such a localized accumulation of fluvial deposits accounts for the lack of Unit 1 in the distal part of sector 2, which probably experienced sediment starvation and bypass. The occurrence of Unit 1 in the proximal part of sector 3, suggests that the river outflowed from the Siena Basin dismantling its eastern rocky shoulder and producing an exceeding sediment load that locally congested the valley.

The onset of deposition of Unit 2 (Figure 17C) occurred as a consequence of the activations of F1-F3 faults, which strongly modified the valley bottom profile and caused the development of localized depocenters and valley shift in the proximal part of sector 2 . The movement of the F1 fault caused the subsidence in sector 1, inducing an overall decrease in transport capability of the valley, with accumulation of overbank-dominated fluvial deposits within the valley and gravel deposition restricted to tributary inlets along the valley flanks. As the area sited downstream of F1 fault underwent uplift, the axis of fluvial incision within the valley progressively shifted towards the hydrographic left, a 
process ascribed to the increase of the F1 fault displacement towards the south-east. The progressive dismantling of this uplifted block caused aggradation of gravelly and sandy deposits in the proximal and distal parts of the sector 2, respectively. In sector 2, the shift of the major river occurred in parallel with the activation of the Terre Rosse Fault (Figures 2 and 4), that caused a development of alluvial fans along the left-hand side of the valley flank/north flank of the valley? Although exposures are limited at the present day, similar processes occurred in association with fault F2 and F3. Specifically, the coarse sediments produced by the dismantling of the F2 footwall were trapped in the subsiding area developed upstream of $\mathrm{F} 3$ fault, as attested by borehole data.

The deposition of Unit 3 was associated with a dramatic reorganization of the river network (Figure 17D). The major river abandoned the valley, and in sector 1 the Ambra River started to flow northward following the establishment of the modern watershed between the Upper Valdarno Basin and the Siena Basin. This caused incision and terracing of Unit 2 mud in the modern Ambra River valley. The Ombrone River was the only tributary of the major valley, that was flooded in sector 2 as a consequence of damming due to F2 fault. The lake had probably an emissary in its southern termination, as suggested by the gravelly-floored abandoned valley now drained by the Bestina Creek. The fragmentation of the valley caused also a development of palustrine conditions in sector 3 , that was dammed by F3 fault. Intense tectonic activity during this phase is also testified by the occurrence of syn-sedimentary faults and dewatering structures in the lacustrine deposits of the NE to Rapolano Terme.

The last depositional stage was associated with the establishment of the present-day drainage (Figure 17E). The Ambra River kept terracing its modern valley, mainly following entrenching of the Arno River in the Valdarno Basin [22]. The lake developed in sector 2 was emptied following a capture from a SE draining watercourse. This event caused a deflection of the Ombrone River toward SW along with the abandonment of the lake emissary that nowadays is drained by the Bestina Creek. The fluvial incision and the terracing of sector 2 was followed by accumulation of travertines, which were formed from precipitation of thermal water sourced by fault F2 and F3.

The proposed reconstruction frames the evolution of the studied palaeovalley between the regional marine regression and the accumulation of travertine and coeval fluvial terraced deposits (i.e., Unit 4), that occurred at 2.5 my and 40-150 kyrs, respectively. The diversion of the Ambra River toward north, at the transition between Unit 2 and 3, followed the entrance of the Arno River in the Upper Valdarno Basin just before the Matuyama/Brunhes transition $[31,33,36]$ at $0.78 \mathrm{Ma}$. In this frame, the change from reverse to normal polarity detected by [22] in the middle part of the Unit 1 could be ascribed to the base of either Olduvai or Jaramillo sub-chrons. However, if marine sedimentation persisted in the Siena Basin until latest Gelasian, as suggested by [42], such a reverse polarity would correspond to the base of the Jaramillo sub-chron.

The thickness of the channel bars in the fluvial deposits of Unit 1 and 2 indicate that the palaeo-channels draining the valley were up to $4-5 \mathrm{~m}$ deep. Using a palaeohydrological approach, [22] estimated a bankfull discharge of ca. $266 \mathrm{~m}^{3} \mathrm{~s}^{-1}$ for a palaeochannel of Unit 1. Although the river discharge strongly depends by local runoff, the value is comparable with that one of the modern Arno River at its entrance in the Upper Valdarno Basin, suggesting that the studied palaeovalley was drained by a major fluvial system. Nevertheless, further geological investigations and detailed provenance studies are required to reconstruct the origin of this fluvial system.

\subsection{Lifecycle of an Intermontane Fluvial Valley}

The incision of the studied valley system occurred after a tectonically-driven, regional uplift that caused a marine forced regression in the whole inner sector of Northern Apennines [16]. Therefore, the development of the valley matches with classical stratigraphic models, that relate the incision of valleys in coastal areas to episodes of base level fall and a dramatic subtraction of accommodation space [1]. These models also predict a wide 
spectrum of processes to fill incised valleys in coastal areas, although all of them required a relative sea-level rise, which allowed an increase of available accommodation space within the valley [3], heading its progressive backfilling according with the available sediment supply [1]. The infill of the valley cannot be ascribed to a relative sea-level rise since regional doming, in combination with the occurrence of inherited Neogene morpho-structural sills, prevented the sea from reentering southern Tuscany after the late Piacentian forced regression $[16,77]$. The aggradation within the valley can be ascribed to an unsteady sediment balance, and specifically to a progressive increase of sediment influx in comparison with the ebb [1]. This unsteadiness in sediment balance was differently manifested during accumulation of Unit 1-4. The tectonic uplift of the Chianti Ridge (i.e., one of the source area of the study palaeo-drainage) occurred at the Piacentian to Gelasian transition and it is represented by progressive unconformities in the basin-fill succession of the neighboring Upper Valdarno Basin [78]. Such an uplift enhanced the amount of sediment supplied into the valley and it triggered aggradation of Unit 1, especially at the entrance of the valley in the Siena Basin (sectors 1 and 2), where an abrupt decrease of gradient occurred. In sector 2, the valley-scale muddy overbank deposits might have been accumulated in response to an upstream gravel trapping, due to the localized decrease in the valley gradient associated with the activation of the F1 fault system. After dropping most of its load at the entrance of the Siena Basin, the river entrained new bedload crossing the F3 fault zone and it dropped it just downstream following a further morphotectonic-induced gradient decrease. Localized sediment trapping was furtherly enhanced during accumulation of Unit 2. At this stage the rate of F1-3 footwall uplift outpaced that one of the river embanking, forming localized barriers that strongly impacted on river transport capability and fluvial styles (cf. [75]). The desertion of the major river from the valley enhanced modifications of depositional dynamics during the accumulation of Unit 3 and 4, when the sector 1 hosted a reversed (i.e., northward) and shrank fluvial drainage (i.e., Ambra River), and sectors $2-3$ acted as small fluvio-palustrine basins.

The reconstructed depositional history shows that incision and filling of the valley were, therefore, linked to a relative-sea level drop and morpho-tectonic forcings, respectively. This marks the difference between the studied succession and most of the documented valley fills, highlighting that forcings causing incision and filling of a valley do not have to be genetically related [79]. Additionally, the occurrence of fluvial, lacustrine and travertines deposits of Units 3 and 4 shows that the process of tectonic segmentation of the major valley might cause a large spatial differentiation of depositional dynamics which contributes to accumulate successions that are hardly identified in the rock record as the infill of ancient valleys. The wide spectrum of deposits filling the study valley is also a precious archive of climate and tectonic events affecting the area since latest Piacentian.

The three main depositional phases recognized in travertine and terraced deposits of Unit 4 assist in the understanding of the complex relationship between local tectonic uplift, fluvial morphodynamics and climate. The travertine deposition, that is often related to humid periods allowing the recharge of thermal reservoir, is an important evidence in this complexity. This situation was illustrated in other Italian travertine examples [80-83] evidencing how such recharge is directly related to the climatic conditions of the oddnumbered Marine Isotope Stages. Also in Rapolano Terme area, the sum of the available data evidence this relation and how, on the short period, the climate exerts a fundamental control on travertine deposition and on the development of alluvial/aggradational phases.

During the Pleistocene tectonic evolution of the inner Northern Apennines, relationships between fault activities and the evolution of the continental sedimentation strongly support a sedimentary response related to the tectonic pulses during the Quaternary. In particular, the activity of the Querciolaia and Violante-San Gimignanello faults (Figure 2), as well as the whole fault segments forming the "Arbia-Valmarecchia" shear zone, controlled the drainage and fluvio-lacustrine sedimentation during the Pleistocene and Holocene, thus attesting their primary role in controlling the continental sedimentation and the hydrographic pattern from Middle Pleistocene to Holocene. This reinforces the 
fact that, according to [52], the study area was affected by significant tectonic activity during Pleistocene-Holocene times, in response to a transtensive (mainly left-lateral) stress field $[51,53,55]$. Soft-sediment deformation structures (i.e., seismites) triggered by ground shacking present in the lacustrine sediments of the Unit 3 (Figure 13), indicate that the tectonic activity was accompanied by seismic events during the Middle Pleistocene. This completes the seismotectonic framework bringing back in time the beginning of the seismic activity in the study area, before referred to an oldest age of $84 \pm 8-48.92 \pm 5.08 \mathrm{ka}$ [54]. This adds fundamental information for the better understanding of the seismotectonic framework and it sheds lights on the seismic potential of this sector of Tuscany, considered of modest interest with respect to seismic hazard and risk issues.

\section{Conclusions}

A Pleistocene palaeovalley and related deposits were recognized and mapped over a distance of ca. $35 \mathrm{~km}$ at the border between three major extensional intermontane basins of the Northern Apennines (Upper Valdarno, Siena and Val di Chiana Basin). This palaeovalley was cut following the regional late Piacentian marine forced regression, and it was filled since Gelasian following the intense tectonic activity that caused a progressive increase of sediment influx in comparison to the ebb. The major results produced from this work can be summarized as follow:

- Forcings causing incision and filling of a valley do not have to be genetically related. Although the study valley was cut as consequence of a relative sea-level fall, alluvial aggradation valley was not driven by a relative sea-level rise but resulted from an increase in sediment supply and a tectonic-driven sediment trapping within the valley.

- Tectonic segmentation of a valley can cause a wide spectrum of depositional environments within the major valley trunk. The occurrence of fluvial, lacustrine and travertines deposits in the studied valley-fill succession account for this process and highlight that such a large spatial variability of sedimentary facies can hinder detection of ancient valleys in the rock record.

- The wide spectrum of deposits filling the tectonically-segmented valley is an archive for tectono-climatic events. Specifically, it arises that the inner sector of Norther Apennines was affected by a significant tectonic activity during Pleistocene-Holocene times, in response to a transtensive stress field.

Author Contributions: Conceptualization, M.G., A.B., E.C., M.A., V.B.; formal analysis, T.-L.Y., C.C.S.; investigation, M.G., A.B., E.C., M.A., V.B.; writing—original draft preparation, M.G., A.B., E.C.; writing-review and editing, M.G., A.B., E.C., M.A., V.B. All authors have read and agreed to the published version of the manuscript.

Funding: This research was funded by University of Padova (DOR2018 funds M.G.).

Data Availability Statement: Data are available following request to corresponding author.

Acknowledgments: M.G., A.B. and E.C. authors are indebted with R. Pancino for the remarkable support in the field. Marta Cosma and two anonymous reviewers are acknowledged for reading and commenting an early version of this work. U-Th dating in the HISPEC was supported by grants from the Science Vanguard Research Program of the Ministry of Science and Technology (MOST), Taiwan, ROC (109-2123-M-002-001 to C.-C.S.), the Higher Education Sprout Project of the Ministry of Education, Taiwan, ROC (109L901001 to C.-C.S.), the National Taiwan University (110L8907 to C.-C.S.)

Conflicts of Interest: The authors declare no conflict of interest.

\section{References}

1. Zaitlin, B.A.; Dalrymple, R.W.; Boyd, R. The Stratigraphic Organization of Incised-Valley Systems Associated with Relative Sea-Level Change. In Incised-Valley Systems: Origin and Sedimentary Sequences; Dalrymple, R., Boyd, R., Zaitlin, B.A., Eds.; SEPM Society for Sedimentary Geology: Tulsa, OK, USA, 1994; Volume SEPM SP 51, pp. 45-60. ISBN 9781565760905. 
2. Corner, G.D. A Transgressive-Regressive Model of Fjord-Valley Fill: Stratigraphy, Facies and Depositional Controls. In Incised Valleys in Time and Space; Dalrymple, R., Leckie, D., Tillman, R., Eds.; SEPM Society for Sedimentary Geology: Tulsa, OK, USA, 2006; Volume SEPM SP 85, pp. 161-178, ISBN 1565761227.

3. Simms, A.R.; Anderson, J.B.; Taha, Z.P.; Rodriguez, A.B. Overfilled versus Underfilled Incised Valleys: Examples from the Quaternary Gulf of Mexico. In Incised Valleys in Time and Space; Dalrymple, R., Leckie, D., Tillman, R., Eds.; SEPM Society for Sedimentary Geology: Tulsa, OK, USA, 2006; Volume SEPM SP 85, pp. 117-139, ISBN 1565761227.

4. Deibert, J.E.; Camilleri, P.A. Sedimentologic and tectonic origin of an incised-valley-fill sequence along an extensional marginallacustrine system in the Basin and Range province, United States: Implications for predictive models of the location of incised valleys. Am. Assoc. Pet. Geol. Bull. 2006, 90, 209-235. [CrossRef]

5. Garrison, J.R., Jr.; van den Bergh, T.C.V. Effects of Sedimentation Rate, Rate of Relative Rise in Sea Level, and Duration of Sea-Level Cycle on the Filling of Incised Valleys: Examples of Filled and overfilled Incised Valleys From the Upper Ferron Sandstone, Last Chance Delta, East-Central Utah. In Incised Valleys in Time and Space; Dalrymple, R., Leckie, D., Tillman, R., Eds.; Special Publications of SEPM: Tulsa, OK, USA, 2006; Volume SEPM SP 85, pp. 239-279.

6. Plink-Björklund, P.; Steel, R.J. Incised Valleys On An Eocene Coastal Plain And Shelf, Spitsbergen-Part of A Linked Shelf-Slope System. In Incised Valleys in Time and Space; Dalrymple, R., Leckie, D., Tillman, R., Eds.; SEPM Society for Sedimentary Geology: Tulsa, OK, USA, 2006; Volume SEPM SP 85, pp. 281-307, ISBN 1565761227.

7. Gobo, K.; Ghinassi, M.; Nemec, W.; Sjursen, E. Development of an incised valley-fill at an evolving rift margin: Pleistocene eustasy and tectonics on the southern side of the Gulf of Corinth, Greece. Sedimentology 2014, 61, 1086-1119. [CrossRef]

8. Boyd, R.; Dalrymple, R.W.; Zaitlin, B.A. Estuarine and Incised-Valley Facies Models. In Facies Models Revisited; Walker, R.G., Posamentier, H., Eds.; SEPM Society for Sedimentary Geology: Tulsa, OK, USA, 2006; Volume SEPM SP 84, pp. 171-235. ISBN 9781565763302.

9. Blum, M.D.; Törnqvist, T.E. Fluvial responses to climate and sea-level change: A review and look forward. Sedimentology 2000, 47, 2-48. [CrossRef]

10. Holbrook, J. Origin, genetic interrelationships, and stratigraphy over the continuum of fluvial channel-form bounding surfaces: An illustration from middle Cretaceous strata, Southeastern Colorado. Sediment. Geol. 2001, 144, 179-222. [CrossRef]

11. Vincent, S.J. The Sis palaeovalley: A record of proximal fluvial sedimentation and drainage basin development in response to Pyrenean mountain building. Sedimentology 2001, 48, 1235-1276. [CrossRef]

12. Gibling, M.R.; Fielding, C.R.; Sinha, R. Alluvial Valleys and Alluvial Sequences:Towards a Geomorphic Assessment. In From River to Rock Record: The Preservation of Fluvial Sediments and Their Subsequent Interpretation; Davidson, S.K., Leleu, S., North, C.P., Eds.; SEPM Society for Sedimentary Geology: Tulsa, OK, USA, 2011; Volume SEPM SP 97, pp. 423-447, ISBN 9781565763050.

13. Hain, M.P.; Strecker, M.R.; Bookhagen, B.; Alonso, R.N.; Pingel, H.; Schmitt, A.K. Neogene to Quaternary broken foreland formation and sedimentation dynamics in the Andes of NW Argentina (25 ${ }^{\circ}$ S). Tectonics 2011, 30, 1-27. [CrossRef]

14. Mey, J.; Scherler, D.; Zeilinger, G.; Strecker, M.R. Estimating the fill thickness and bedrock topography in intermontane valleys using artificial neural networks. J. Geophys. Res. Earth Surf. 2015, 120, 1301-1320. [CrossRef]

15. Wang, P.; Scherler, D.; Liu-Zeng, J.; Mey, J.; Avouac, J.-P.; Zhang, Y.; Shi, D. Tectonic control of Yarlung Tsangpo Gorge revealed by a buried canyon in Southern Tibet. Science 2014, 346, 978-981. [CrossRef]

16. Martini, I.P.; Sagri, M. Tectono-sedimentary characteristics of Late Miocene-Quaternary extensional basins of the Northern Apennines, Italy. Earth-Sci. Rev. 1993, 34, 197-233. [CrossRef]

17. Cosentino, D.; Asti, R.; Nocentini, M.; Gliozzi, E.; Kotsakis, T.; Mattei, M.; Esu, D.; Spadi, M.; Tallini, M.; Cifelli, F.; et al. New insights into the onset and evolution of the central Apennine extensional intermontane basins based on the tectonically active L'Aquila Basin (central Italy). Bull. Geol. Soc. Am. 2017, 129, 1314-1336. [CrossRef]

18. Bartolini, C.; D'Agostino, N.; Dramis, F. Topography, exhumation, and drainage network evolution of the Apennines. Episodes 2003, 26, 212-216. [CrossRef]

19. D'Agostino, N.; Jackson, J.A.; Dramis, F.; Funiciello, R. Interactions between mantle upwelling, drainage evolution and active normal faulting: An example from the Central Appennines (Italy). Geophys. J. Int. 2001, 147, 475-497. [CrossRef]

20. Piacentini, T.; Miccadei, E. The role of drainage systems and intermontane basins in the Quaternary landscape of the Central Apennines chain (Italy). Rend. Lincei 2014, 25, 139-150. [CrossRef]

21. Bartolini, C.; Pranzini, G. Plio-Quaternary evolution of the Arno basin drainage. Z. Geomorphol. Suppl. Stuttg. 1981, 40, 77-91.

22. Bianchi, V.; Ghinassi, M.; Aldinucci, M.; Boaga, J.; Brogi, A.; Deiana, R. Tectonically driven deposition and landscape evolution within upland incised valleys: Ambra Valley fill, Pliocene-Pleistocene, Tuscany, Italy. Sedimentology 2015, 62, 897-927. [CrossRef]

23. Bianchi, V.; Salles, T.; Ghinassi, M.; Billi, P.; Dallanave, E.; Duclaux, G. Numerical modeling of tectonically driven river dynamics and deposition in an upland incised valley. Geomorphology 2015, 241, 353-370. [CrossRef]

24. Liotta, D.; Cernobori, L.; Nicolicl, R. Restricted rifting and its coexistence with compressional structures: Results from the CROP 3 traverse (Northern Apennines, Italy). Terra Nova 1998, 10, 16-20. [CrossRef]

25. Carmignani, L.; Decandia, F.A.; Disperati, L.; Fantozzi, P.L.; Kligfield, R.; Lazzarotto, A.; Liotta, D.; Meccheri, M. Inner Northern Apennines. In Anatomy of an Orogen: The Apennines and Adjacent Mediterranean Basins; Vai, G.B., Martini, I.P., Eds.; Springer: Dordrecht, The Netherlands, 2001; pp. 197-213, ISBN 978-94-015-9829-3. 
26. Carmignani, L.; Decandia, F.A.; Dispera, L.; Fantozzi, P.L.; Lazzarotto, A.; Oggiano, G.; Angioj, V.C.M. Relationships between the Tertiary structural evolution of the Sardinia-Corsica-Provençal Domain and the Northern Apennines. Terra Nova 1995, 7, 128-137. [CrossRef]

27. Nalin, R.; Ghinassi, M.; Foresi, L.M.; Dallanave, E. Carbonate deposition in restricted basins: A Pliocene case study from the central Mediterranean (Northwestern Apennines), Italy. J. Sediment. Res. 2016, 86, 236-267. [CrossRef]

28. Brogi, A.; Liotta, D. Highly extended terrains, lateral segmentation of the substratum, and basin development: The middle-late Miocene Radicondoli Basin (inner northern Apennines, Italy). Tectonics 2008, 27, 1-20. [CrossRef]

29. Barchi, M.R. The Neogene-Quaternary evolution of the Northern Apennines: Crustal structure, style of deformation and seismicity. J. Virtual Explor. 2010, 36. [CrossRef]

30. Sagri, M.; Magi, M. Il Bacino del Valdarno Superiore. Soc. Geol. Ital. L'Appennino Settentr. Guid. Alle Escursioni Post-Congr. 1992, $201,226$.

31. Albianelli, A.; Bertini, A.; Magi, M.; Napoleone, G.; Sagri, M. Il bacino Plio-Pleistocenico del Valdarno Superiore: Eventi deposizionali, paleomagnetici e paleoclimatici. Quaternario 1995, 8, 11-18.

32. Ghinassi, M.; Magi, M. Variazioni climatiche, tettonica e sedimentazione al passaggio Pliocene medio-Pliocene superiore nel bacino del Valdarno Superiore (Appennino Settentrionale). Ital. J. Geosci. 2004, 123, 301-310.

33. Fidolini, F.; Ghinassi, M.; Magi, M.; Papini, M.; Sagri, M. The Plio-Pleistocene fluvio-lacustrine Upper Valdarno Basin (Central Italy): Stratigraphy and Basin fill evolution. Ital. J. Geosci. 2013, 132, 13-32. [CrossRef]

34. Rook, L.; Croitor, R.; Delfino, M.; Ferretti, M.P.; Gallai, G.; Pavia, M. The Upper Valdarno Plio-Pleistocene vertebrate record: An historical overview, with notes on palaeobiology and stratigraphic significance of some important taxa. Ital. J. Geosci. 2013, 132, 104-125. [CrossRef]

35. Billi, P.; Magi, M.; Sagri, M. Coarse-Grained Low-Sinuosity River Deposits: Example from Plio-Pleistocene Valdarno Basin, Italy. In Recent Developments in Fluvial Sedimentolology; SEPM Society for Sedimentary Geology: Tulsa, OK, USA, 1987 ; pp. 197-203.

36. Fidolini, F.; Ghinassi, M.; Aldinucci, M.; Billi, P.; Boaga, J.; Deiana, R.; Brivio, L. Fault-sourced alluvial fans and their interaction with axial fluvial drainage: An example from the Plio-Pleistocene Upper Valdarno Basin (Tuscany, Italy). Sediment. Geol. 2013, 289, 19-39. [CrossRef]

37. Bonini, M.; Sani, F. Extension and compression in the Northern Apennines (Italy) hinterland: Evidence from the late MiocenePliocene Siena-Radicofani Basin and relations with basement structures. Tectonics 2002, 21, 1-35. [CrossRef]

38. Brogi, A. Bowl-shaped basin related to low-angle detachment during continental extension: The case of the controversial Neogene Siena Basin (central Italy, Northern Apennines). Tectonophysics 2011, 499, 54-76. [CrossRef]

39. Martini, I.; Aldinucci, M.; Foresi, L.M.; Mazzei, R.; Sandrelli, F. Geological map of the Pliocene succession of the Northern Siena Basin (Tuscany, Italy). J. Maps 2011, 7, 193-205. [CrossRef]

40. Martini, I.; Arragoni, S.; Aldinucci, M.; Foresi, L.M.; Bambini, A.M.; Sandrelli, F. Detection of detached forced-regressive nearshore wedges: A case study from the central-southern Siena Basin (Northern Apennines, Italy). Int. J. Earth Sci. 2013, 102, 1467-1489. [CrossRef]

41. Martini, I.; Aldinucci, M. Sedimentation and basin-fill history of the pliocene succession exposed in the Northern Siena-Radicofani Basin (Tuscany, Italy): A sequence-stratigraphic approach. Riv. Ital. Paleontol. Stratigr. 2017, 123, 407-432. [CrossRef]

42. Baldanza, A.; Bizzarri, R.; Famiani, F.; Garassino, A.; Hyžný, M.; Pasini, G. The bathyal decapod crustacean community from the Poggio i Sodi quarries (Siena Basin, Tuscany, Italy). Bol. Soc. Geol. Mex. 2013, 65, 335-353. [CrossRef]

43. Barchi, M.; Minelli, G.; Magnani, B.; Mazzotti, A. Line CROP 03: Northern Apennines. Mem. Descr. Cart. Geol. d’It. 2003, LXII, 127-136.

44. Bizzarri, R.; Baldanza, A. Integrated stratigraphy of the marine Early Pleistocene in Umbria. Geosciences 2020, 10, 371. [CrossRef]

45. Aruta, G.; Borgia, A.; Bruni, P.; Cecchi, G.; Cipriani, N.; Tredici, Y. Pliocene and Pleistocene unconformity bounded stratigraphic units (UBSU) in Val di Chiana. In The "Regione Toscana" Project of Geological Mapping: Case Histories and Data Acquisition; Morini, D., Bruni, P., Eds.; Tipografia Martinelli: Bagno a Ripoli, Italy, 2004; pp. 133-136.

46. Rook, L.; Martínez-Navarro, B. Villafranchian: The long story of a Plio-Pleistocene European large mammal biochronologic unit. Quat. Int. 2010, 219, 134-144. [CrossRef]

47. Brogi, A. Late evolution of the inner Northern Apennines from the structure of the Monti del Chianti-Monte Cetona ridge (Tuscany, Italy). J. Struct. Geol. 2020, 141, 104205. [CrossRef]

48. Liotta, D. Analisi del settore centro-meridionale del bacino pliocenico di Radicofani (Toscana meridionale). Boll. Soc. Geol. Ital. 1996, 115, 115-143.

49. Pascucci, V.; Martini, I.P.; Sagri, M.; Sandrelli, F. Effects of Transverse Structural Lineaments on the Neogene-Quaternary Basins of Tuscany (Inner Northern Apennines, Italy). In Sedimentary Processes, Environments and Basins: A Tribute to Peter Friend; Nichols, G., Williams, E., Paola, C., Eds.; John Wiley \& Sons: Hoboken, NJ, USA, 2007; pp. 155-182, ISBN 9781405179225.

50. Bambini, A.M.; Brogi, A.; Cornamusini, G.; Costantini, A.; Foresi, L.M.; Lazzarotto, A. Geologia dell'area di Rapolano Terme in provincia di Siena (Appennino Settentrionale). Ital. J. Geosci. 2010, 129, 457-495. [CrossRef]

51. Brogi, A.; Capezzuoli, E.; Aqué, R.; Branca, M.; Voltaggio, M. Studying travertines for neotectonics investigations: Middle-Late Pleistocene syn-tectonic travertine deposition at Serre di Rapolano (Northern Apennines, Italy). Int. J. Earth Sci. 2010, 99, 1383-1398. [CrossRef] 
52. Brogi, A.; Capezzuoli, E.; Martini, I.; Picozzi, M.; Sandrelli, F. Late quaternary tectonics in the inner Northern apennines (Siena Basin, southern Tuscany, Italy) and their seismotectonic implication. J. Geodyn. 2014, 76, 25-45. [CrossRef]

53. Brogi, A.; Capezzuoli, E.; Kele, S.; Baykara, M.O.; Shen, C.C. Key travertine tectofacies for neotectonics and palaeoseismicity reconstruction: Effects of hydrothermal overpressured fluid injection. J. Geol. Soc. 2017, 174, 679-699. [CrossRef]

54. Brogi, A.; Capezzuoli, E.; Moretti, M.; Olvera-García, E.; Matera, P.F.; Garduno-Monroy, V.H.; Mancini, A. Earthquake-triggered soft-sediment deformation structures (seismites) in travertine deposits. Tectonophysics 2018, 745, 349-365. [CrossRef]

55. Brogi, A. Faults linkage, damage rocks and hydrothermal fluid circulation: Tectonic interpretation of the Rapolano Terme travertines (southern Tuscany, Italy) in the context of Northern Apennines Neogene-Quaternary extension. Eclogae Geol. Helv. 2004, 97, 307-320. [CrossRef]

56. Brogi, A.; Capezzuoli, E. Travertine deposition and faulting: The fault-related travertine fissure-ridge at Terme S. Giovanni, Rapolano Terme (Italy). Int. J. Earth Sci. 2009, 98, 931-947. [CrossRef]

57. Brogi, A.; Capezzuoli, E. Earthquake impact on fissure-ridge type travertine deposition. Geol. Mag. 2014, 151, 1135-1143. [CrossRef]

58. Liotta, D. The Arbia-Val Marecchia line, Northern Apennines. Eclogae Geol. Helv. 1991, 84, 413-430.

59. Shen, C.C.; Cheng, H.; Edwards, R.L.; Moran, S.B.; Edmonds, H.N.; Hoff, J.A.; Thomas, R.B. Measurement of attogram quantities of 231Pa in dissolved and particulate fractions of seawater by isotope dilution thermal ionization mass spectroscopy. Anal. Chem. 2003, 75, 1075-1079. [CrossRef]

60. Shen, C.C.; Wu, C.C.; Cheng, H.; Lawrence Edwards, R.; Hsieh, Y.T.; Gallet, S.; Chang, C.C.; Li, T.Y.; Lam, D.D.; Kano, A.; et al. High-precision and high-resolution carbonate ${ }^{230}$ Th dating by MC-ICP-MS with SEM protocols. Geochim. Cosmochim. Acta 2012, 99, 71-86. [CrossRef]

61. Shen, C.C.; Lawrence Edwards, R.; Cheng, H.; Dorale, J.A.; Thomas, R.B.; Bradley Moran, S.; Weinstein, S.E.; Edmonds, H.N. Uranium and thorium isotopic and concentration measurements by magnetic sector inductively coupled plasma mass spectrometry. Chem. Geol. 2002, 185, 165-178. [CrossRef]

62. Cheng, H.; Edwards, R.L.; Shen, C.C.; Polyak, V.J.; Asmerom, Y.; Woodhead, J.; Hellstrom, J.; Wang, Y.; Kong, X.; Spötl, C.; et al. Improvements in ${ }^{230} \mathrm{Th}$ dating, ${ }^{230} \mathrm{Th}$ and ${ }^{234} \mathrm{U}$ half-life values, and U-Th isotopic measurements by multi-collector inductively coupled plasma mass spectrometry. Earth Planet. Sci. Lett. 2013, 371-372, 82-91. [CrossRef]

63. Brogi, A.; Fidolini, F.; Liotta, D. Tectonic and sedimentary evolution of the Upper Valdarno Basin: New insights from the lacustrine S. Barbara Basin. Ital. J. Geosci. 2013, 132, 81-97. [CrossRef]

64. Aldinucci, M.; Ghinassi, M.; Sandrelli, F. Climatic and tectonic signature in the fluvial infill of a late Pliocene valley (Siena Basin, Northern Apennines, Italy). J. Sediment. Res. 2007, 77, 398-414. [CrossRef]

65. Esu, D.; Girotti, O. Late Pliocene and Pleistocene assemblages of continental molluscs in Italy. A survey. Quaternario 1991, 4, 137-150.

66. Martinson, D.G.; Pisias, N.G.; Hays, J.D.; Imbrie, J.; Moore, T.C.; Shackleton, N.J. Age dating and the orbital theory of the ice ages: Development of a high-resolution 0 to 300,000-year chronostratigraphy. Quat. Res. 1987, 27, 1-29. [CrossRef]

67. Hiess, J.; Condon, D.J.; McLean, N.; Noble, S.R. ${ }^{238} \mathrm{U} /{ }^{235} \mathrm{U}$ systematics in terrestrial uranium-bearing minerals. Science 2012, 335, 1610-1615. [CrossRef] [PubMed]

68. Minissale, A.; Vaselli, O.; Tassi, F.; Magro, G.; Grechi, G.P. Fluid mixing in carbonate aquifer near Rapolano (central Italy): Chemical and isotopic constraints. Appl. Geochem. 2002, 17, 1329-1342. [CrossRef]

69. Minissale, A. Origin, transport and discharge of $\mathrm{CO}_{2}$ in central Italy. Earth-Sci. Rev. 2004, 66, 89-141. [CrossRef]

70. Jaffey, A.H.; Flynn, K.F.; Glendenin, L.E.; Bentley, W.C.; Essling, A.M. Precision measurement of half-lives and specific activities of ${ }^{235} \mathrm{U}$ and ${ }^{238} \mathrm{U}$. Phys. Rev. C 1971, 4, 1889-1906. [CrossRef]

71. Capezzuoli, E.; Gandin, A.; Pedley, H.M. Travertines and calcareous tufa in southern Tuscany (central Italy). In 27th IAS Meeting of Sedimentology, Alghero, Italy. Fieldtrip Guidebook; Pascucci, V., Andreucci, S., Eds.; EDES: Alghero, Italy, 2009; pp. 129-158, ISBN 9788865280652.

72. Guo, L.; Riding, R. Hot-spring travertine facies and sequences, Late Pleistocene, Rapolano Terme, Italy. Sedimentology 1998, 45, 163-180. [CrossRef]

73. Guo, L.; Riding, R. Rapid facies changes in Holocene fissure ridge hot spring travertines, Rapolano Terme, Italy. Sedimentology 1999, 46, 1145-1158. [CrossRef]

74. Carrara, C.; Ciuffarella, L.; Paganin, G. Inquadramento geomorfologico e climatico ambientale dei travertini di Rapolano Terme (SI). Ital. J. Quat. Sci. 1998, 11, 319-329.

75. Mancini, A.; Capezzuoli, E.; Erthal, M.; Swennen, R. Hierarchical approach to define travertine depositional systems: 3D conceptual morphological model and possible applications. Mar. Pet. Geol. 2019, 103, 549-563. [CrossRef]

76. Capezzuoli, E.; Gandin, A.; Pedley, M. Decoding tufa and travertine (fresh water carbonates) in the sedimentary record: The state of the art. Sedimentology 2014, 61, 1-21. [CrossRef]

77. Bossio, A.; Costantini, A.; Lazzarotto, A.; Liotta, D.; Mazzanti, R.; Salvatorini, G.; Sandrelli, F. Rassegna delle conoscenze sulla stratigrafia del Neoautoctono toscano. Mem. Soc. Geol. Ital. 1993, 49, 17-98.

78. Ghinassi, M.; Abbazzi, L.; Esu, D.; Gaudant, J.; Girotti, O. Facies analysis, stratigraphy and palaeontology (Molluscs and Vertebrates) in the Upper Pliocene sandy flood-basin deposits of the Upper Valdarno Basin (Northern Apennines). Riv. Ital. Paleontol. Stratigr. 2005, 111, 467-487. [CrossRef] 
79. Holbrook, J.; Schumm, S.A. Geomorphic and sedimentary response of rivers to tectonic deformation: A brief review and critique of a tool for recognizing subtle epeirogenic deformation in modern and ancient settings. Tectonophysics 1999, 305, 287-306. [CrossRef]

80. Soligo, M.; Tuccimei, P.; Barberi, R.; Delitala, M.C.; Miccadei, E.; Taddeucci, A. U/Th dating of freshwater travertine from Middle Velino Valley (Central Italy): Paleoclimatic and geological implications. Palaeogeogr. Palaeoclimatol. Palaeoecol. 2002, 184, 147-161. [CrossRef]

81. Faccenna, C.; Soligo, M.; Billi, A.; De Filippis, L.; Funiciello, R.; Rossetti, C.; Tuccimei, P. Late Pleistocene depositional cycles of the Lapis Tiburtinus travertine (Tivoli, Central Italy): Possible influence of climate and fault activity. Glob. Planet. Chang. 2008, 63, 299-308. [CrossRef]

82. Janssens, N.; Capezzuoli, E.; Claes, H.; Muchez, P.; Yu, T.L.; Shen, C.C.; Ellam, R.M.; Swennen, R. Fossil travertine system and its palaeofluid provenance, migration and evolution through time: Example from the geothermal area of Acquasanta Terme (Central Italy). Sediment. Geol. 2020, 398, 105580. [CrossRef]

83. Mancini, A.; Della Porta, G.; Swennen, R.; Capezzuoli, E. 3D reconstruction of the Lapis Tiburtinus (Tivoli, Central Italy): Glacio-eustasy variations affecting travertine deposition. Basin Res. 2021. accepted. 